\title{
Climate versus emission drivers of methane lifetime against loss by tropospheric OH from 1860-2100
}

\author{
J. G. John ${ }^{1}$, A. M. Fiore ${ }^{1, *}$, V. Naik ${ }^{2}$, L. W. Horowitz ${ }^{1}$, and J. P. Dunne ${ }^{1}$ \\ ${ }^{1}$ Geophysical Fluid Dynamics Laboratory/NOAA, Princeton, New Jersey, USA \\ ${ }^{2}$ UCAR/Geophysical Fluid Dynamics Laboratory, Princeton, New Jersey, USA \\ * now at: Department of Earth and Environmental Sciences, and Lamont-Doherty Earth Observatory \\ of Columbia University, Palisades, NY, USA
}

Correspondence to: J. G. John (jasmin.john@noaa.gov)

Received: 31 May 2012 - Published in Atmos. Chem. Phys. Discuss.: 20 July 2012

Revised: 17 November 2012 - Accepted: 26 November 2012 - Published: 19 December 2012

\begin{abstract}
With a more-than-doubling in the atmospheric abundance of the potent greenhouse gas methane $\left(\mathrm{CH}_{4}\right)$ since preindustrial times, and indications of renewed growth following a leveling off in recent years, questions arise as to future trends and resulting climate and public health impacts from continued growth without mitigation. Changes in atmospheric methane lifetime are determined by factors which regulate the abundance of $\mathrm{OH}$, the primary methane removal mechanism, including changes in $\mathrm{CH}_{4}$ itself. We investigate the role of emissions of short-lived species and climate in determining the evolution of methane lifetime against loss by tropospheric $\mathrm{OH},\left(\tau_{\mathrm{CH} 4 \mathrm{-OH}}\right)$, in a suite of historical (1860-2005) and future Representative Concentration Pathway (RCP) simulations (2006-2100), conducted with the Geophysical Fluid Dynamics Laboratory (GFDL) fully coupled chemistry-climate model (CM3). From preindustrial to present, $\mathrm{CM} 3$ simulates an overall $5 \%$ increase in $\tau_{\mathrm{CH} 4-\mathrm{OH}}$ due to a doubling of the methane burden which offsets coincident increases in nitrogen oxide $\left(\mathrm{NO}_{\mathrm{x}}\right)$ emissions. Over the last two decades, however, the $\tau_{\mathrm{CH} 4 . \mathrm{OH}}$ declines steadily, coinciding with the most rapid climate warming and observed slow-down in $\mathrm{CH}_{4}$ growth rates, reflecting a possible negative feedback through the $\mathrm{CH}_{4}$ sink. Sensitivity simulations with CM3 suggest that the aerosol indirect effect (aerosolcloud interactions) plays a significant role in cooling the CM3 climate. The projected decline in aerosols under all RCPs contributes to climate warming over the 21 st century, which influences the future evolution of $\mathrm{OH}$ concentration and $\tau_{\text {СH4_ОН. }}$. Projected changes in $\tau_{\text {Сн4_ОН }}$ from 2006 to 2100 range from $-13 \%$ to $+4 \%$. The only projected increase oc-
\end{abstract}

curs in the most extreme warming case (RCP8.5) due to the near-doubling of the $\mathrm{CH}_{4}$ abundance, reflecting a positive feedback on the climate system. The largest decrease occurs in the RCP4.5 scenario due to changes in short-lived climate forcing agents which reinforce climate warming and enhance $\mathrm{OH}$. This decrease is more-than-halved in a sensitivity simulation in which only well-mixed greenhouse gas radiative forcing changes along the RCP4.5 scenario ( $5 \%$ vs. $13 \%$ ).

\section{Introduction}

Atmospheric methane $\left(\mathrm{CH}_{4}\right)$ is the second most important anthropogenic greenhouse gas after carbon dioxide $\left(\mathrm{CO}_{2}\right)$, reflecting its stronger heat-trapping efficiency (100-yr global warming potential of 25) and more-than-doubling in abundance since pre-industrial times (Forster et al., 2007). As a precursor to global tropospheric ozone $\left(\mathrm{O}_{3}\right)$ (e.g., Prather et al., 2003), the third most important greenhouse gas, methane exerts an additional indirect influence on climate (Shindell et al., 2005), as well as on background levels of surface $\mathrm{O}_{3}$ (Fiore et al., 2002), with corresponding adverse impacts on human health (West et al., 2006). Quantifying climate impacts requires an estimate of the $\mathrm{CH}_{4}$ lifetime, which is largely determined by its loss via reaction with the hydroxyl radical $(\mathrm{OH}$, Levy et al., 1971) in the troposphere, $\left(\tau_{\mathrm{CH} 4 . \mathrm{OH}}\right)$. The $\mathrm{OH}$ distribution, in turn, is strongly influenced by changes in both climate and emissions. Furthermore, since methane is an important sink for $\mathrm{OH}$, any change in the methane abundance is amplified via a positive feedback on 
$\tau_{\text {Сн4-Он }}$ and thereby on the climate system (Prather, 1994). We investigate here the relative importance of changes in climate factors (temperature, $\mathrm{OH}$, water vapor $\left(\mathrm{H}_{2} \mathrm{O}\right)$, lightning $\mathrm{NO}_{\mathrm{x}}\left(\mathrm{LNO}_{\mathrm{x}}\right)$, photolysis rates) versus anthropogenic emissions $\left(\mathrm{CH}_{4}\right.$ abundance, carbon monoxide $(\mathrm{CO})$ and nitrous oxide $\left.\left(\mathrm{NO}_{\mathrm{x}}\right)\right)$ in contributing to changes in the $\tau_{\mathrm{CH} 4 \mathrm{OH}}$ from 1860 to 2100 , in the context of the new set of historical and future emission scenarios (Lamarque et al., 2010; Meinshausen et al., 2011; van Vuuren et al., 2011) developed for the fifth phase of the Coupled Model Intercomparison Project (CMIP5) (Taylor et al., 2012), in support of the Intergovernmental Panel on Climate Change (IPCC) Fifth Assessment (AR5).

The best constraints on $\tau_{\mathrm{CH} 4 . \mathrm{OH}}$ in the contemporary atmosphere are from top-down estimates on global mean $\mathrm{OH}$ inferred from methyl chloroform $\left(\mathrm{CH}_{3} \mathrm{CCl}_{3}\right)$ measurements which indicate a $\tau_{\text {Сн4-Он }}$ of $10.2_{-0.7}^{+0.9}$ for the period 1978-2004 (Prinn et al., 2005). For comparison, recent multi-model estimates for $\tau_{\mathrm{CH} 4 \text {-Он }}$ fall within this range $10.2 \pm 1.7 \mathrm{yr}$ (Fiore et al., 2009), and $9.8 \pm 1.6 \mathrm{yr}$ (Voulgarakis et al., 2012), and $9.90_{-1.76}^{+1.68} \mathrm{yr}$ (Stevenson et al., 2006, derived from their reported total lifetime of $8.67 \pm 1.32 \mathrm{yr}$ ). A multi-year modeling study for 1979-1993 estimates a $\tau_{\text {СH4.ОH }}$ of $9.0 \pm 0.13 \mathrm{yr}$ (Dentener et al., 2003). Prather et al. (2012) have recently estimated an observationally-derived present-day $\tau_{\mathrm{CH}_{-} \text {Он }}$ of $11.2 \pm 1.3 \mathrm{yr}$, which includes updated best estimates, with uncertainties, for the factors contributing to the atmospheric methane budget. This new estimate suggests models may overestimate the loss by tropospheric $\mathrm{OH}$, consistent with the underestimate of $\mathrm{CO}$ and overestimate of $\mathrm{O}_{3}$ in the current generation of chemical transport and chemistry-climate models (Naik et al., 2012b; Young et al., 2012).

Combining $\tau_{\text {Сн4.ОН }}$ with estimates for other methane loss processes which include absorption by soils $(120 \mathrm{yr}$, Prather et al., 2012), stratospheric destruction (150 yr, Prather et al., 2012), and possibly oxidation by atomic chlorine in the marine atmospheric boundary layer (200 yr, Allan et al., 2007) yields a present-day total atmospheric lifetime of $9.1 \pm 0.9 \mathrm{yr}$ (Prather et al., 2012). The approximate balance of the methane budget, as evidenced by the observed nearconstant methane abundance from 1999 until 2007 (Dlugokencky et al., 2009; Rigby et al., 2008), suggests that these methane sinks balanced the source globally. While the global methane source is thus fairly well constrained, the contributions from individual source sectors are poorly constrained, along with any temporal variability in their relative importance. Methane emission from wetlands dominates the natural source, with smaller contributions from termites, oceans and methane hydrates.Various anthropogenic $\mathrm{CH}_{4}$ sources (rice paddies, ruminants, coal and natural gas, landfills and biomass burning) together account for over $60 \%$ of the present-day global budget (Table 7.6 in Denman et al., 2007). Overall, annual source and sink strengths are estimated at $582 \pm 87 \mathrm{Tg} \mathrm{CH}_{4}$ and $581 \pm 87 \mathrm{Tg} \mathrm{CH}_{4}$, respectively (Denman et al., 2007).
Prior studies have established the dominant role of the tropical lower troposphere in oxidation of $\mathrm{CH}_{4}$ due to high $\mathrm{OH}$ abundance and temperatures (as the $\mathrm{CH}_{4}+\mathrm{OH}$ reaction rate constant is strongly sensitive to temperature, $\sim 2 \%$ $\mathrm{K}^{-1}$ ) (Logan et al., 1981; Prather and Spivakovsky, 1990; Crutzen and Zimmermann, 1991; Crutzen et al., 1999, Spivakovsky et al., 2000), with estimates ranging from 75$78 \% \mathrm{CH}_{4}$ loss in the tropics and $79-90 \% \mathrm{CH}_{4}$ loss below $500 \mathrm{hPa}$ (Spivakovsky et al., 2000; Lawrence et al., 2001; Fiore et al., 2008). The $\mathrm{OH}$ abundance and distribution reflect a complex interplay among various factors including anthropogenic and natural emissions, as well as meteorological processes that may change with climate. Increases in atmospheric $\mathrm{CH}_{4}$ burden, carbon monoxide, and nonmethane volatile organic compounds (NMVOCs) all act to decrease $\mathrm{OH}$ concentrations and increase the methane lifetime. Increases in UV (photolysis frequencies viz. $\mathrm{J}\left(\mathrm{O}^{1} \mathrm{D}\right)$ ), water vapor, and nitrogen oxide sources tend to increase $\mathrm{OH}$, which in turn decreases the lifetime of methane. The non-linearities in $\mathrm{OH}$ chemistry complicate definitive attributions to individual processes controlling $\mathrm{OH}$ (e.g., Spivakovsky et al., 2000). Furthermore, the relative importance of individual $\mathrm{OH}$ sources and sinks varies widely by region (e.g., Lelieveld et al., 2004).

The potential for these various, sometimes offsetting, factors to influence $\mathrm{OH}$ poses a substantial challenge to accurate identification of the processes driving $\mathrm{OH}$ trends and variability. While observations of $\mathrm{CH}_{3} \mathrm{CCl}_{3}$ and the atmospheric methane growth rate could theoretically provide constraints on OH trends over recent decades (Dlugokencky et al., 1998; Spivakovsky et al., 2000; Prinn et al., 2005), attributing small changes (a few percent of the large $\mathrm{CH}_{4}$ atmospheric abundance) unambiguously to the many individual processes exerting multiple competing influences on $\mathrm{OH}$ is complicated. For example, Krol et al. (1998) report a positive $\mathrm{OH}$ trend of $0.46 \% \mathrm{yr}^{-1}$ from 1978-1993 due to combination of stratospheric $\mathrm{O}_{3}$ loss, reduced carbon monoxide concentrations, and increases in water vapor abundance and $\mathrm{NO}_{\mathrm{x}}$ emissions, while Dentener et al. (2003) identify water vapor as the major driver of increases in OH from 1979 to 1993 (Table 2). Hypotheses to explain the decade-long near-zero growth rate of atmospheric methane range from a steady-state equilibrium of methane sources and sinks (Dlugokencky et al., 1998), to decreases in natural and/or anthropogenic emissions (e.g., Kai et al., 2011; Aydin et al., 2011), to variations in meteorological factors and processes (e.g., Fiore et al., 2006; Hodson et al., 2011; cf. Table 2). Fewer constraints exist for the change in $\mathrm{OH}$ since the pre-industrial period, with estimates ranging from a $33 \%$ decrease to a $7 \%$ increase (cf. Table 1), although a recent multi-model study suggests little change (Naik et al., 2012b).

We use a state-of-the-art fully coupled global climatechemistry model, the Geophysical Fluid Dynamics Laboratory Coupled Model version 3 (CM3) to examine the drivers and trends of $\tau_{\text {сн4-Он }}$. We focus our analysis 
Table 1. Percent changes in methane lifetime and $\mathrm{OH}$ compiled from literature. Note that the definition of methane lifetime is not necessarily the same in references below.

\begin{tabular}{|c|c|c|}
\hline Reference & $\begin{array}{l}\% \text { Change in Methane } \\
\text { Lifetime since preindustrial }\end{array}$ & Method \\
\hline Osborn and Wigley $(1994)^{\mathrm{a}}$ & $+15 \%$ to $+34 \%$ & parameterized model \\
\hline Martinerie et al. $(1995)^{\mathrm{a}}$ & $-14.1 \%$ & 2-D model \\
\hline Lelieveld et al. $(1998)^{\mathrm{b}}$ & $+27.4 \%$ & 3-D model \\
\hline Unger et al. $(2009)^{\mathrm{a}}$ & $+13 \%,+11.6 \%$ & $\begin{array}{l}\text { 3-D model (with, w/o aerosol-cloud } \\
\text { interactions) }\end{array}$ \\
\hline \multirow[t]{2}{*}{ Søvde et al. $(2011)^{\mathrm{a}}$} & $+4.6 \%,+4.0 \%$ & 3-D model (with, w/o \\
\hline & & $\left.\mathrm{HO}_{2}+\mathrm{NO} \rightarrow \mathrm{HNO}_{3}\right)$ \\
\hline Reference & $\begin{array}{l}\% \text { Change in } \mathrm{OH} \\
\text { since preindustrial }\end{array}$ & Method \\
\hline Staffelbach et al. (1991) & $-30 \%$ & $\begin{array}{l}\text { ice core measurements of } \\
\mathrm{CH}_{2} \mathrm{O}\end{array}$ \\
\hline Crutzen and Zimmerman (1991) & $-10 \%$ to $-20 \%$ & 3-D model \\
\hline Thompson et al. (1993) & $-20 \%$ & Multi 1-D model \\
\hline Martinerie et al. (1995) & $+6 \%$ & 2-D model \\
\hline Berntsen et al. (1997) & $+6.8 \%$ & 3-D model \\
\hline Roelofs et al. (1997) & $-22 \%$ & 3-D model \\
\hline Brasseur et al. (1998) & $-17 \%$ & 3-D model \\
\hline Wang and Jacob (1998) & $-9 \%$ & 3-D model \\
\hline Mickley et al. (1999) & $-16 \%$ & 3-D model \\
\hline Grenfell et al. (2001) & $-4 \%$ & $\begin{array}{l}\text { 3-D model without non-methane } \\
\text { hydrocarbon (NMHC) }\end{array}$ \\
\hline Hauglustaine and Brasseur (2001) & $-33 \%$ & 3-D model \\
\hline Shindell et al. (2001) & $-5.9 \%$ & 3-D model \\
\hline Lelieveld et al. (2002) & $-5 \%$ & 3-D model \\
\hline Lamarque et al. (2005) & $-8 \%$ & 3-D model \\
\hline Shindell et al. (2006) & $-16 \%$ & 3-D model \\
\hline Sofen et al. (2011) & $-10 \%$ & 3-D model \\
\hline
\end{tabular}

a Tropospheric lifetime with respect to $\mathrm{OH}$ or chemical lifetime.

b Total lifetime (includes all loss processes).

on the role of changes in anthropogenic emissions $\left(\mathrm{CH}_{4}\right.$ and gas-phase $\mathrm{OH}$ precursors) versus climate (temperature, water vapor, photolysis rates, lightning $\mathrm{NO}_{\mathrm{x}}$ ) on the evolution of $\tau_{\text {Сн4.ОН }}$ on decadal-to-century time scales in a suite of historical simulations and future scenarios. This new tool allows investigation of a broader suite of chemistry-climate interactions and is intended to complement multi-model comparisons conducted for specific decadal time periods such as those occurring under the Atmospheric Chemistry and Climate Model Intercomparison Project (ACCMIP) in support of IPCC AR5.

\section{Model description and simulations}

The Geophysical Fluid Dynamics Laboratory CM3 Model incorporates an atmospheric chemistry model within the fully interactive framework of the atmosphere, ocean, land, and sea-ice components (Donner et al., 2011; Naik et al., 2012a; Griffies et al., 2011; C. Milly, personal communica- tion, 2012; Shevliakova et al., 2009). We provide here a summary of the features most relevant to the simulation of $\mathrm{OH}$.

The CM3 model simulates interactive tropospheric and stratospheric chemistry, achieved by merging the mechanisms from MOZART-2 (Horowitz et al., 2003) and AMTRAC (Austin and Wilson, 2006), respectively, as described by Naik et al. (2012a) who evaluate global trace gas distributions over recent decades with in situ measurements of $\mathrm{O}_{3}$ and other $\mathrm{OH}$ precursors. The model simulates atmospheric concentrations of 97 chemical species, 12 of which are aerosol species. Photolysis rates are parameterized by a lookup table for clear-sky conditions and are modified to account for clouds, but are not directly affected by changes in aerosols. The model accounts for the radiative effects of aerosols ("direct effect"), as well as the impact of aerosols on liquid cloud droplet formation ("indirect effect") (Donner et al., 2011). In addition, heterogeneous reactions (including those of $\mathrm{N}_{2} \mathrm{O}_{5}$ and $\mathrm{NO}_{3}$ ) on the surface of aerosols are included in the chemical mechanism. 
Table 2. Summary of major drivers of methane and $\mathrm{OH}$ trends, growth rates and interannual variability (IAV) from previous studies.

\begin{tabular}{|c|c|c|c|}
\hline Reference & Time Period & Major drivers of $\mathrm{CH}_{4}$ trends, growth rates and IAV & Method \\
\hline Law and Nisbet (1996) & 1980-1994 & $\begin{array}{l}\text { decline in } \mathrm{CH}_{4} \text { growth rate from } 1989-1992 \text { due } \\
\text { to reductions in fossil fuel emissions from former Soviet Union }\end{array}$ & 2-D model \\
\hline Bekki and Law (1997) & 1980-1992 & $\begin{array}{l}\text { decline in } \mathrm{CH}_{4} \text { growth rate due to temperature } \\
\text { dependency of rate constant and } \mathrm{CH}_{4} \text { emissions from wetlands }\end{array}$ & 2-D model \\
\hline Dlugokencky et al. (1998) & $1984-1996$ & $\begin{array}{l}\text { decrease in } \mathrm{CH}_{4} \text { growth rate due to approach } \\
\text { to steady state }\end{array}$ & Observations/Analysis \\
\hline Hamilton and Fan (2000) & $1980-1999$ & $\begin{array}{l}\text { stratospheric quasi-biennial oscillation contributes } \\
\text { to } \mathrm{CH}_{4} \text { growth rate }\end{array}$ & 3-D model \\
\hline Karlsdóttir and Isaksen (2000) & $1980-1996$ & increasing anthropogenic emissions in SE Asia & $\begin{array}{l}\text { 3-D model, } \\
\text { fixed annual meteorology }\end{array}$ \\
\hline Johnson et al. (2002) & 1990-2009 & $\begin{array}{l}\mathrm{CH}_{4} \text { interannual variability driven by } \mathrm{OH} \\
\text { (water vapor) }\end{array}$ & 3-D model \\
\hline Warwick et al. (2002) & $1980-1998$ & $\begin{array}{l}\mathrm{CH}_{4} \text { interannual variability due to } \\
\text { vertical redistribution and transport changes }\end{array}$ & 3-D model \\
\hline Dlugokencky et al. (2003) & $1984-2002$ & equilibrium/steady state; wetlands & Observations/Analysis \\
\hline Wang et al. (2004) & $1988-1997$ & $\begin{array}{l}\text { decrease in } \mathrm{CH}_{4} \text { growth rate due to } \\
\text { reduced anthropogenic emissions, increasing } \mathrm{OH}\end{array}$ & 3-D model \\
\hline Bousquet et al. (2006) & 1984-2003 & $\begin{array}{l}\text { decline in anthropogenic emissions; } \\
\text { wetland emissions }\end{array}$ & Inversion \\
\hline Fiore et al. (2006) & 1990-2004 & increasing $\mathrm{OH}$ and temperature & 3-D model \\
\hline Aydin et al. (2011) & $1980-2000$ & reduced fossil fuel emissions & Firn air measurements \\
\hline Hodson et al. (2011) & $1950-2005$ & ENSO variability & Wetland $\mathrm{CH}_{4}$ model \\
\hline Kai et al. (2011) & 1984-2005 & reduced emissions from rice paddies in Asia & Isotopic constraints \\
\hline Reference & Time Period & OH trends, growth rates and IAV & Method \\
\hline Prinn et al. (1995) & 1978-1994 & $\mathrm{OH}$ trend: $0.0 \pm 0.2 \% \mathrm{yr}^{-1}$ & Observations/Analysis \\
\hline Krol et al. (1998) & $1978-1993$ & $\begin{array}{l}\text { positive } \mathrm{OH} \text { trend }\left(0.46 \pm 0.6 \% \mathrm{yr}^{-1}\right) \\
\text { due to stratospheric } \mathrm{O}_{3} \text { depletion, declining } \mathrm{CO} \text {, } \\
\text { increased water vapor and } \mathrm{NO}_{\mathrm{x}} \text { emissions }\end{array}$ & $\begin{array}{l}3 \text {-D model, } \\
1 \text { yr of analyzed wind data }\end{array}$ \\
\hline Karlsdóttir and Isaksen (2000) & $1980-1996$ & $\begin{array}{l}\text { positive } \mathrm{OH} \text { trend }\left(0.43 \% \mathrm{yr}^{-1}\right) \text { due to changes } \\
\text { in } \mathrm{CO}, \mathrm{NO}_{\mathrm{x}} \text { and } \mathrm{NMHC} \text { emissions }\end{array}$ & $\begin{array}{l}\text { 3-D model, } \\
\text { fixed annual meteorology }\end{array}$ \\
\hline Prinn et al. (2001) & $1978-2000$ & negative $\mathrm{OH}$ trend: $-0.64 \pm 0.60 \% \mathrm{yr}^{-1}$ & Observations/Analysis \\
\hline Dentener et al. (2003) & $1979-1993$ & $\begin{array}{l}\text { positive } \mathrm{OH} \text { trend }\left(0.24 \pm 0.06 \% \mathrm{yr}^{-1}\right) \text { due to } \\
\text { changes in water vapor in tropical troposphere }\end{array}$ & 3-D model \\
\hline Wang et al. (2004) & $1988-1997$ & $\begin{array}{l}\text { positive } \mathrm{OH} \text { trend }\left(0.64 \% \mathrm{yr}^{-1}\right) \\
\text { due to decrease in column } \mathrm{O}_{3}\end{array}$ & 3-D model \\
\hline Bousquet et al. (2005) & $1979-2000$ & $\begin{array}{l}\text { negative } \mathrm{OH} \text { trend after } 1980 \\
\left(-0.7 \pm 0.2 \% \mathrm{yr}^{-1}\right)\end{array}$ & Inversion \\
\hline Dalsøren and Isaksen (2006) & $1990-2001$ & $\begin{array}{l}\text { positive } \mathrm{OH} \text { trend }\left(0.08 \% \mathrm{yr}^{-1}\right) \\
\text { from varying } \mathrm{CO}, \mathrm{NO}_{\mathrm{x}}, \mathrm{NMVOC} \text { emissions }\end{array}$ & $\begin{array}{l}\text { 3-D model, } \\
\text { fixed annual meteorology }\end{array}$ \\
\hline Montzka et al. (2011) & $1998-2007$ & $\mathrm{OH}$ interannual variability: $2.3 \pm 1.5 \%$ & $\mathrm{CH}_{3} \mathrm{CCl}_{3}$ observations \\
\hline
\end{tabular}

Emissions of $\mathrm{CH}_{4}$, nitrous oxide $\left(\mathrm{N}_{2} \mathrm{O}\right)$, and ozonedepleting substances (ODS) are not simulated in CM3. For $\mathrm{CH}_{4}$ and $\mathrm{N}_{2} \mathrm{O}$, concentrations for chemistry below $800 \mathrm{hPa}$ are restored to historical or RCP values (Meinshausen et al., 2011), with a timestep of 1 day. For ODS, volume mixing ratios are prescribed as a lower boundary condition, with the source of reactive chlorine and bromine in the stratosphere parameterized following Austin and Wilson (2010). The impact of climate change on $\mathrm{CH}_{4}$ emissions from wetlands (and any other natural sources); from wildfires; and from other biogenic precursors to $\mathrm{OH}$ which can influence the $\mathrm{CH}_{4}$ lifetime (such as NMVOC and soil nitrogen oxide emissions); are not included. The model applies climatological biogenic isoprene and soil $\mathrm{NO}_{\mathrm{x}}$ emissions as in Horowitz (2006). Lightning $\mathrm{NO}_{\mathrm{x}}\left(\mathrm{LNO}_{\mathrm{x}}\right)$ is the only natural source that is tied to the model meteorology and thus can respond to changes in climate. The parameterization of both continental and oceanic lightning $\mathrm{NO}_{\mathrm{x}}$ is based on empirical relationships between convective cloud top heights and lightning flash frequencies as in Horowitz et al. (2003), Price et al. (1997) and Levy et al. (1996). 
Table 3. Summary of forcings and emissions used in CM3/CMIP5 simulations. All simulations use dynamic vegetation, except for 1860 CONTROL which uses static vegetation.

\begin{tabular}{|c|c|c|c|c|c|c|c|c|}
\hline Experiment & Solar & Volcanoes & $\begin{array}{l}\text { WMGHG } \\
\text { (radiation) }\end{array}$ & $\begin{array}{l}\text { WMGHG } \\
\text { (chemistry) }\end{array}$ & $\begin{array}{l}\text { Aerosol } \\
\text { emission }\end{array}$ & $\begin{array}{l}\text { Ozone } \\
\text { Precursors } \\
\text { (emission/conc) }\end{array}$ & LandUse & $\begin{array}{l}\text { Radiative and } \\
\text { Land } \mathrm{CO}_{2}\end{array}$ \\
\hline CONTROL & 1860 & none & 1860 & 1860 & 1860 & 1860 & 1860 & 1860 \\
\hline $\operatorname{HIST}(5)^{\mathrm{a}}$ & Historical & Historical & Historical & Historical & Historical & Historical & Historical & Historical \\
\hline AEROSOL $^{b}(3)$ & 1860 & none & 1860 & 1860 & Historical & 1860 & 1860 & 1860 \\
\hline $\begin{array}{l}\text { AEROSOL } \\
\text { INDIRECT (3) }\end{array}$ & 1860 & none & 1860 & 1860 & 1860 climatology & 1860 & 1860 & 1860 \\
\hline ANTHRO (3) & 1860 & none & Historical & Historical & Historical & Historical & Historical & Historical \\
\hline NATURAL $^{\mathrm{c}}(3)$ & Historical & Historical & 1860 & 1860 & 1860 & 1860 & 1860 & 1860 \\
\hline $\mathrm{WMGGO}^{\mathrm{d}}$ (3) & 1860 & none & Historical & Historical & 1860 & Historical & 1860 & Historical \\
\hline $\mathrm{RCP} 2.6$ & $\mathrm{RCP} 2.6$ & none & $\mathrm{RCP} 2.6$ & $\mathrm{RCP} 2.6$ & RCP2.6 & $\mathrm{RCP} 2.6$ & $\mathrm{RCP} 2.6$ & $\mathrm{RCP} 2.6$ \\
\hline RCP4.5 (3) & $\mathrm{RCP} 4.5$ & none & $\mathrm{RCP} 4.5$ & $\mathrm{RCP} 4.5$ & $\mathrm{RCP} 4.5$ & $\mathrm{RCP} 4.5$ & $\mathrm{RCP} 4.5$ & $\mathrm{RCP} 4.5$ \\
\hline $\mathrm{RCP} 4.5^{* \mathrm{e}}(3)$ & $\mathrm{RCP} 4.5$ & none & $\mathrm{RCP} 4.5$ & $\begin{array}{l}2005 \text { for } \mathrm{CH}_{4}, \\
\mathrm{~N}_{2} \mathrm{O}, \text { ODS }\end{array}$ & 2005 & 2005 & $\mathrm{RCP} 4.5$ & $\mathrm{RCP} 4.5$ \\
\hline RCP6.0 & RCP6.0 & none & RCP6.0 & RCP6.0 & RCP6.0 & RCP6.0 & RCP6.0 & RCP6.0 \\
\hline RCP8.5 & RCP8.5 & none & RCP8.5 & RCP8.5 & RCP8.5 & RCP8.5 & RCP8.5 & RCP8.5 \\
\hline
\end{tabular}

a Number in parentheses next to experiment names denotes the number of ensemble members.

b AEROSOL: only aerosols, $\mathrm{SO}_{2} / \mathrm{BC} / \mathrm{OC}$ emissions are time-varying.

c NATURAL: GHG for radiation and chemistry fixed at 1860 values. CFCs fixed at 1860 values.

d WMGGO3: $\mathrm{SO}_{2}$ and aerosols held at 1860 values.

e RCP4.5*: $\mathrm{CH}_{4}, \mathrm{~N}_{2} \mathrm{O}$ and ODS for chemistry are fixed at 2005 values. Aerosol and $\mathrm{O}_{3}$ precursor emissions also fixed to 2005 values.

Table 3 provides a summary of the CM3 model simulations analyzed here. A multi-century 1860 Control integration (CONTROL) using prescribed (static) vegetation and constant 1860 land use fractions was performed initially, and five historical ensembles (HIST) were branched from CONTROL after achieving a stable, realistic climate. Both vegetation dynamics and land use (defined as land use change plus harvesting) were activated in the land model component of CM3 for all historical simulations and future projections.

In addition to the historical model ensemble where all forcings vary in time as described by Lamarque et al. (2010), additional "single-forcing" experiments were conducted in which the forcing of interest is allowed to vary with time, with other forcings held constant at 1860 levels. The specifications for these 3-member ensemble simulations, viz. AEROSOL, AEROSOL INDIRECT, ANTHRO, NATURAL, and WMGGO3, are described in Table 3. The AEROSOL simulations include both the direct (radiative) effect and warm-cloud aerosol indirect effect. In AEROSOL INDIRECT, aerosol and aerosol precursor emissions vary as in HIST, but an 1860 climatology taken from years 1-20 of CONTROL is used for radiation. Thus, AEROSOL INDIRECT includes the warm-cloud aerosol indirect effect on clouds (and the effect of aerosol changes on heterogeneous reaction rates), but does not include direct (radiative) forcing changes by aerosols. The difference between the AEROSOL and AEROSOL INDIRECT simulations provides an estimate of the aerosol direct effect. In ANTHRO, only anthropogenic forcings (viz., aerosols, ozone, greenhouse gases) vary over the historical period while natural forcings are held constant.
In NATURAL, only solar and volcanic forcings are allowed to change. The WMGGO3 simulation isolates the influences from changing only well-mixed greenhouse gases and ozone. Land use fractions are held at 1860 values (i.e., there are no land use transitions) in AEROSOL, AEROSOL INDIRECT, NATURAL and WMGGO3. $\mathrm{CO}_{2}$ concentrations for radiation and land plant photosynthesis are held constant at the 1860 value of $286.15 \mathrm{ppm}$ in AEROSOL, AEROSOL INDIRECT and NATURAL. These simulations can be used to investigate key drivers of overall historical changes, to isolate the "forced" response (i.e., to anthropogenic emissions), and to separate climate drivers (temperature, $\mathrm{H}_{2} \mathrm{O}, \mathrm{J}\left(\mathrm{O}^{1} \mathrm{D}\right)$, lightning $\mathrm{NO}_{\mathrm{x}}$ ) from anthropogenic emission drivers ( $\mathrm{CO}$ and $\mathrm{NO}_{\mathrm{x}}$ emissions, $\mathrm{CH}_{4}$ concentrations) of methane lifetime.

Future projections use time-varying forcings as recommended for the new Representative Concentration Pathway (RCP) scenarios developed for CMIP5 in support of IPCC AR5 (Table 3). The scenarios are labeled according to the year 2100 nominal radiative forcing (RF), which ranges from 2.6 to $8.5 \mathrm{Wm}^{-2}$ (Moss et al., 2010). In all four RCP scenarios, emissions of aerosols and their precursors, as well as of non-methane $\mathrm{OH}$ precursors (i.e., $\mathrm{NO}_{\mathrm{x}}, \mathrm{NMVOC}, \mathrm{CO}$ ) are assumed to decline, under the assumption of aggressive air pollution abatement strategies (van Vuuren et al., 2011). An additional 3-member model ensemble (RCP4.5*), is identical to RCP4.5, but with aerosol emissions, $\mathrm{O}_{3}$ precursors, $\mathrm{CH}_{4}, \mathrm{~N}_{2} \mathrm{O}$ and ODS for chemistry held at year 2005 values. Comparing the methane lifetime evolution in RCP4.5 and RCP4.5* enables us to examine the role of climate warming 
Table 4. Mean and standard deviation $(\sigma)$ of annual mean methane lifetime with respect to $\mathrm{OH}$ loss, $\tau_{\mathrm{CH} 4-\mathrm{OH}}$, (yr), and correlation coefficient ( $r$ ) of $\tau_{\mathrm{CH} 4 \text { _OH }}$ with global annual mean airmass-weighted $\mathrm{OH}$ and temperature (both below $500 \mathrm{hPa}$ ), in CM3/CMIP5 simulations. All values are reported over the length of model simulation periods (146 yr for historical, $95 \mathrm{yr}$ for RCPs), except for $\tau_{\mathrm{CH}_{4} \mathrm{OOH} \_1986-2005}$, the methane lifetime against loss by tropospheric $\mathrm{OH}$ over the last $20 \mathrm{yr}$ (1986-2005) of the historical ensemble. For all statistics, we first average annual means over all ensemble members to obtain the ensemble mean time series. We then report the mean and standard deviation over the full length of the simulations (column 2), or from 1986-2005 (column 3).

\begin{tabular}{llcrr}
\hline Experiment & $\begin{array}{l}\tau_{\text {CH4_OH }} \\
\text { Mean } \pm \sigma \\
(\mathrm{yr})\end{array}$ & $\begin{array}{c}\tau_{\text {СH4_OH_1986-2005 }} \\
\text { Mean } \pm \sigma \\
(\mathrm{yr})\end{array}$ & $\begin{array}{r}r_{-} \text {OH } \\
\text { (below } \\
500 \mathrm{hPa})\end{array}$ & $\begin{array}{r}r_{-} \text {TEMP } \\
(\mathrm{below} \\
500 \mathrm{hPa})\end{array}$ \\
\hline HIST & $8.63 \pm 0.24$ & $8.67 \pm 0.16$ & -0.97 & -0.19 \\
AEROSOL & $8.50 \pm 0.22$ & $8.88 \pm 0.04$ & -0.99 & -0.99 \\
AEROSOL & $8.52 \pm 0.21$ & $8.88 \pm 0.04$ & -0.99 & -0.98 \\
INDIRECT & & & & \\
ANTHRO & $8.44 \pm 0.22$ & $8.62 \pm 0.08$ & -0.98 & 0.25 \\
NATURAL & $8.45 \pm 0.13$ & $8.48 \pm 0.12$ & -0.98 & -0.91 \\
WMGGO3 & $8.14 \pm 0.12$ & $7.88 \pm 0.09$ & -0.07 & -0.77 \\
\hline RCP2.6 & $7.72 \pm 0.36$ & & -0.99 & -0.92 \\
RCP4.5 & $7.85 \pm 0.40$ & & -0.98 & -0.98 \\
RCP4.5* & $8.18 \pm 0.16$ & & -0.97 & -0.99 \\
RCP6.0 & $8.41 \pm 0.21$ & & -0.32 & -0.80 \\
RCP8.5 & $8.61 \pm 0.19$ & & -0.90 & 0.78 \\
\hline
\end{tabular}

versus changes in anthropogenic emissions of chemically active species.

\section{Approach}

We define the global annual mean lifetime of methane against loss by tropospheric $\mathrm{OH}, \tau_{\mathrm{CH} 4 . \mathrm{OH}}$, as the quotient of the global total atmospheric methane burden $\left[\mathrm{CH}_{4}\right]$, and the globally integrated $\mathrm{CH}_{4}$ loss rate by reaction with tropospheric $\mathrm{OH}$, $k(T)[\mathrm{OH}]\left[\mathrm{CH}_{4}\right]:$

$$
\tau_{\text {СH4_OH }}=\frac{\int_{\text {surface }}^{\mathrm{TOA}}\left[\mathrm{CH}_{4}\right]}{\int_{\text {surface }}^{\text {tropopause }} k(\mathrm{~T})[\mathrm{OH}]\left[\mathrm{CH}_{4}\right]}
$$

where the rate constant, $k(T)=2.45 \times 10^{-12} e^{-1775 / T}$ $\left(\mathrm{molec}^{-1} \mathrm{~cm}^{-3} \mathrm{~s}^{-1}\right.$ ) is from Sander et al. (2006). The tropopause is defined, separately for each ensemble member, as the model level in which annual mean ozone is $150 \mathrm{ppbv}$. The 1860 model tropopause is then applied to all simulation years. A comparison of tropospheric methane lifetime computed using surface to $200 \mathrm{hPa}$ annual $\mathrm{CH}_{4}$ loss rates in HIST and RCP8.5 yielded values that were within $1 \%$ of those derived using the $150 \mathrm{ppbv} \mathrm{O}_{3}$ tropopause, suggesting that $\tau_{\mathrm{CH} 4 \text {-Он }}$ as calculated here is insensitive to the tropopause definition.

For all statistics, we first average annual means over all ensemble members to obtain the ensemble mean time series. We then report the mean and standard deviation over the full length of the simulations. For our 1860 CONTROL simulation (Table 3), the mean and standard deviation of $\tau_{\text {сн4.ОН }}$ averaged over $200 \mathrm{yr}$ is $8.06 \pm 0.08 \mathrm{yr}$, which is within the range of preindustrial estimates (6.71-12.8 yr) simulated by other models (Martinerie et al., 1995; Unger et al., 2009; Sövde et al., 2011), and $25 \%$ lower than obtained in a recent multi-model study $(10.1 \pm 1.7 \mathrm{yr}$, Naik et al., 2012b). Figure 1 shows the temporal evolution of the global annual mean $\tau_{\text {СH4.ОH }}$ in the CM3/CMIP5 historical simulations and future projections, and in Table 4 we report the mean and standard deviation of $\tau_{\mathrm{CH} 4-\mathrm{OH}}$, as well as the correlation coefficient of $\tau_{\mathrm{CH} 4-\mathrm{OH}}$ with the global mean lower tropospheric (below $500 \mathrm{hPa}$ ) airmass-weighted $\mathrm{OH}$ concentration and temperature, over the full length of the model simulations. The standard deviations in Table 4 reflect trends over the time periods considered and are therefore higher than standard deviation of CONTROL which has no long term trend.

Globally, percent changes in the reaction rate constant $(\Delta k)$ and in $\mathrm{OH}$ abundances in the lower tropical troposphere $(\Delta \mathrm{OH})$ should sum to the magnitude of the overall percent change in methane lifetime against loss by tropospheric $\mathrm{OH}$ $\left(\Delta \tau_{\text {Сн4-ОН }}\right)$, as confirmed in Fig. 2 which shows the linearity between these terms, obtained by differencing $20 \mathrm{yr}$ averages from the start and end of the various model simulations $\left(r^{2}=0.99\right)$. As methane lifetime is determined by temperature and $\mathrm{OH}$, we further refine our analysis by examining the evolution of the sources and sinks of $\mathrm{OH}$, which can be broadly separated into emission factors $\left(\mathrm{CH}_{4}, \mathrm{CO}\right.$, $\mathrm{NO}_{\mathrm{x}}$ ) and climate factors (rate constant, water vapor, lightning $\mathrm{NO}_{\mathrm{x}}$ and photolysis). In Table 5 we present the temperature change, along with percent changes of $\tau_{\mathrm{CH} 4 . \mathrm{OH}}, k$, $\mathrm{OH}, \mathrm{CH}_{4}, \mathrm{CO}$ emissions, surface $\mathrm{NO}_{\mathrm{x}}$ emissions, $\mathrm{LNO}_{\mathrm{x}}$ and $\mathrm{J}\left(\mathrm{O}^{1} \mathrm{D}\right)$ over $20 \mathrm{yr}$ periods at the beginning and end of the model simulations, noting the non-linear interactions of the individual processes in contributing to the net changes in $\mathrm{OH}$. Correlations of $\mathrm{OH}$ with $\mathrm{CH}_{4}, \mathrm{CO}$ emissions, surface $\mathrm{NO}_{\mathrm{x}}$ emissions, the lightning $\mathrm{NO}_{\mathrm{x}}$ source (which is not included in the total $\mathrm{NO}_{\mathrm{x}}$ emissions), lower tropospheric $\mathrm{O}_{3}$ photolysis rates and stratospheric $\mathrm{O}_{3}$ over the full model simulation periods ( $146 \mathrm{yr}$ for historical and $95 \mathrm{yr}$ for RCPs) are reported in Table 6.

Below, we examine the overall drivers of simulated changes in methane lifetime. We further select a few time periods as illustrative examples to separate the roles of changes in climate and anthropogenic emissions in determining the lifetime of methane.

\section{Historical period (1860-2005)}

We first separate the anthropogenic forcing from natural variability by comparing the HIST and ANTHRO ensembles (Table 3). We then further separate ANTHRO into influences from aerosol versus well-mixed greenhouse gases by 


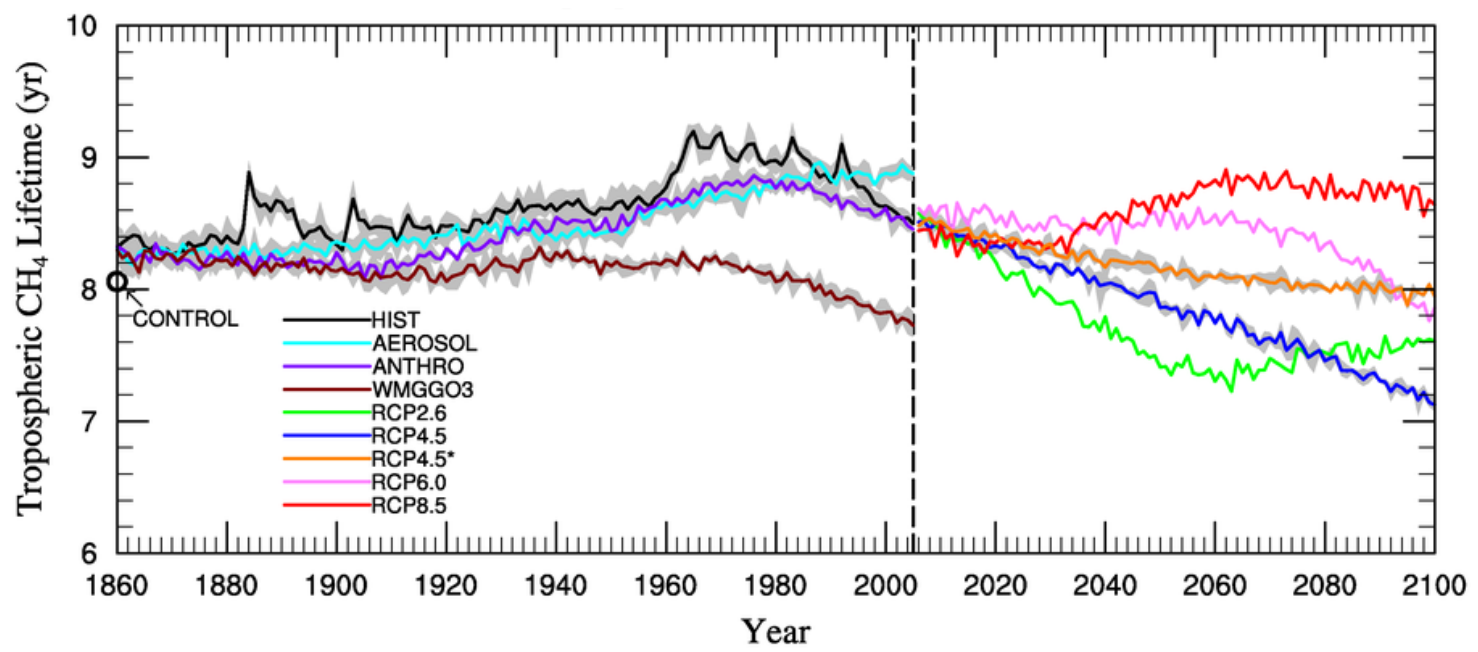

Fig. 1. Evolution of global annual mean methane lifetime against loss by tropospheric $\mathrm{OH}\left(\tau_{\mathrm{CH} 4} \mathrm{OH}\right.$, yr) in GFDL CM3/CMIP5 simulations: HIST (black), AEROSOL (cyan), ANTHRO (purple), WMGGO3 (brown), RCP2.6 (light green), RCP4.5 (dark blue), RCP4.5* (orange), RCP6.0 (pink), RCP8.5 (red). Grey shaded regions indicate the range of ensemble members.

Table 5. Percent change of $\tau_{\mathrm{CH} 4-\mathrm{OH}}$, temperature change ( $\Delta$ TEMP) in Kelvin, percent change of rate constant $(\Delta k), \mathrm{OH}_{(}(\Delta \mathrm{OH}), \mathrm{CH}_{4}\left(\Delta \mathrm{CH}_{4}\right)$, CO emissions ( $\triangle$ COEMIS), surface $\mathrm{NO}_{\mathrm{x}}$ emissions ( $\triangle$ NOEMIS), lightning $\mathrm{NO}_{\mathrm{x}}\left(\Delta \mathrm{LNO}_{\mathrm{x}}\right)$, water vapor $\left(\Delta \mathrm{H}_{2} \mathrm{O}\right)$, and photolysis $\left(\Delta \mathrm{J}\left(\mathrm{O}^{1} \mathrm{D}\right)\right)$ in CM3/CMIP5 simulations, using $20 \mathrm{yr}$ averages (1860-1879 to 1986-2005 for historical, 2006-2025 to 2081-2100 for future projections). Values below $500 \mathrm{hPa}$ are used for temperature, rate constant, $\mathrm{OH}$, water vapor, $\mathrm{LNO}_{\mathrm{x}}$ and $\mathrm{J}\left(\mathrm{O}^{1} \mathrm{D}\right)$. Boxes are shaded only when the direction of the change in the variable matches the indicated $\tau_{\mathrm{CH} 4 \text {-OH }}$ or $\mathrm{OH}$ change. Factors that increase the methane lifetime are denoted by grey shaded boxes with italic text, while dark grey shaded boxes with italic text indicate factors that decrease the methane lifetime. Grey shaded boxes indicate factors that increase $\mathrm{OH}$, while dark grey shaded boxes indicate factors that decrease $\mathrm{OH}$.

\begin{tabular}{lccccccccccc}
\hline Experiment & $\begin{array}{c}\Delta \tau_{\mathrm{CH} 4 \mathrm{OH}} \\
(\%)\end{array}$ & $\begin{array}{c}\Delta \mathrm{TEMP} \\
(\mathrm{K})\end{array}$ & $\begin{array}{c}\Delta k \\
(\%)\end{array}$ & $\begin{array}{c}\Delta \mathrm{OH} \\
(\%)\end{array}$ & $\begin{array}{c}\Delta \mathrm{CH}_{4} \\
(\%)\end{array}$ & $\begin{array}{c}\Delta \mathrm{COEMIS} \\
(\%)\end{array}$ & $\begin{array}{c}\Delta \mathrm{NOEMIS} \\
(\%)\end{array}$ & $\begin{array}{c}\Delta \mathrm{LNO}_{\mathrm{x}} \\
(\%)\end{array}$ & $\begin{array}{c}\Delta \mathrm{H}_{2} \mathrm{O} \\
(\%)\end{array}$ & $\begin{array}{c}\Delta \mathrm{J}\left(\mathrm{O}^{1} \mathrm{D}\right) \\
(\%)\end{array}$ \\
\hline HIST & 5.0 & 0.3 & 0.8 & -6.0 & 108.7 & 117.8 & 329.3 & -2.5 & 2.0 & 0.74 \\
AEROSOL & 7.3 & -1.0 & -2.2 & -4.5 & 0 & 0 & 0 & -6.9 & -5.8 & -1.2 \\
AEROSOL & 6.9 & -0.9 & -2.0 & -4.3 & 0 & 0 & 0 & -4.7 & -5.3 & -1.2 \\
INDIRECT & & & & & & & & & \\
ANTHRO & 4.6 & 0.6 & 1.4 & -6.6 & 108.7 & 117.8 & 329.3 & -1.8 & 4.0 \\
NATURAL & 1.4 & -0.1 & -0.3 & -1.1 & 0 & 0 & 0 & -1.4 & -0.8 & -0.8 \\
WMGGO3 & -4.3 & 2.0 & 4.6 & -1.2 & 108.9 & 117.8 & 329.3 & 4.6 & 12.9 & -0.8 \\
\hline RCP2.6 & -9.1 & 1.1 & 2.5 & 7.3 & -27.1 & -31.1 & -46.5 & 4.4 & 6.8 & 0.4 \\
RCP4.5 & -13.0 & 2.3 & 5.4 & 8.7 & -9.1 & -42.6 & -45.1 & 8.2 & 14.8 & -0.4 \\
RCP4.5* & -5.2 & 1.4 & 3.1 & 2.1 & 0.2 & 0 & 0 & 2.4 & 8.4 & 0.1 \\
RCP6.0 & -5.8 & 2.8 & 6.5 & -0.8 & 2.3 & -17.8 & -46.4 & 11.5 & 18.2 \\
RCP8.5 & 4.3 & 4.5 & 10.8 & -14.8 & 97.2 & -26.2 & -30.2 & 15.0 & 31.1 & -1.2 \\
\hline
\end{tabular}

comparing AEROSOL (and AEROSOL INDIRECT) with WMGGO3.

\subsection{Overall drivers of methane lifetime}

For the HIST five-member ensemble, the global mean $\tau_{\mathrm{CH} 4-\mathrm{OH}}$ over the period 1860 to 2005 is $8.63 \pm 0.24 \mathrm{yr}$ (Table 4), with an overall $5 \%$ increase from $1860-1879$ to $1986-$ 2005. $\tau_{\text {СH4.OH }}$ is strongly anti-correlated with the global mean airmass-weighted $\mathrm{OH}$ below $500 \mathrm{hPa}$ (Table 4), which shows an almost $6 \%$ decrease from 1860-1879 to 1986-2005 (Ta- ble 5). In a sensitivity simulation in which only emissions of $\mathrm{NO}_{\mathrm{x}}, \mathrm{CO}, \mathrm{NMVOC}$, and aerosols (or their precursors) increase from 1860 to 2000, Naik et al. (2012a) find a $14 \%$ decrease in methane lifetime from preindustrial to present. We therefore ascribe the increase in $\tau_{\mathrm{CH} 4 . \mathrm{OH}}$ to the doubling of the global methane burden in HIST, which offsets the decrease in $\tau_{\text {Сн-ОН }}$ due to the quadrupling of surface $\mathrm{NO}_{\mathrm{x}}$ emissions (Table 5). The warming over the historical period has little impact, as demonstrated by the weak correlation with temperature in Table 4. 
Table 6. Correlation coefficients $(r)$ for global annual mean $\mathrm{OH}$ versus global annual total methane burden $\left(\mathrm{CH}_{4}\right)$, $\mathrm{CO}$ emissions $(\mathrm{COEMIS})$, surface $\mathrm{NO}_{\mathrm{x}}$ emissions (NOEMIS), and lightning $\mathrm{NO}_{\mathrm{x}}\left(\mathrm{LNO}_{\mathrm{x}}\right)$; global annual average airmass-weighted water vapor $\left(\mathrm{H}_{2} \mathrm{O}\right)$ and photolysis rates $\left(\mathrm{J}\left(\mathrm{O}^{1} \mathrm{D}\right)\right)$; and global total stratospheric ozone $\left(\mathrm{STRATO}_{3}\right)$, over the length of CM3/CMIP5 model simulation periods (146 yr for historical, $95 \mathrm{yr}$ for RCPs). Values below $500 \mathrm{hPa}$ are used for $\mathrm{OH}$, water vapor, $\mathrm{LNO}_{\mathrm{x}}$ and $\mathrm{J}\left(\mathrm{O}^{1} \mathrm{D}\right)$. Boxes are shaded when they have the correct sign of $r$ to match the sign of $\mathrm{OH}$ change in Table 5. Grey shaded boxes denote variables that have correct sign of $r$ to increase $\mathrm{OH}$. Dark grey shaded boxes indicate variables that have correct sign of $r$ to decrease $\mathrm{OH}$.

\begin{tabular}{lccccccc}
\hline Experiment & $r_{-} \mathrm{CH}_{4}$ & $r_{-}$COEMIS & $r$ NOEMIS & $\begin{array}{c}r \mathrm{LNO}_{\mathrm{x}} \\
\text { (below } \\
500 \mathrm{hPa})\end{array}$ & $\begin{array}{c}r_{-} \mathrm{H}_{2} \mathrm{O} \\
\text { (below } \\
500 \mathrm{hPa})\end{array}$ & $\begin{array}{c}r_{\mathrm{J}}\left(\mathrm{O}^{1} \mathrm{D}\right) \\
(\text { below } \\
500 \mathrm{hPa})\end{array}$ & $r_{-} \mathrm{STRATO}_{3}$ \\
\hline HIST & -0.84 & -0.81 & -0.81 & 0.77 & -0.06 & 0.49 & 0.10 \\
AEROSOL & 0.60 & N/A & N/A & 0.91 & 0.98 & 0.86 & -0.67 \\
AEROSOL & 0.57 & N/A & N/A & 0.82 & 0.96 & 0.84 & -0.63 \\
INDIRECT & & & & & & & \\
ANTHRO & -0.92 & -0.89 & -0.89 & 0.69 & -0.44 & 0.91 & -0.07 \\
NATURAL & 0.34 & N/A & N/A & 0.63 & 0.86 & 0.84 & -0.84 \\
WMGGO3 & -0.67 & -0.62 & -0.62 & -0.35 & -0.57 & 0.82 & -0.25 \\
\hline RCP2.6 & -0.84 & -0.75 & -0.70 & 0.56 & 0.86 & -0.19 & 0.87 \\
RCP4.5 & -0.85 & -0.98 & -0.95 & 0.89 & 0.92 & -0.02 & 0.81 \\
RCP4.5* & 0.89 & N/A & N/A & 0.47 & 0.95 & 0.07 & 0.73 \\
RCP6.0 & -0.97 & 0.08 & 0.28 & -0.08 & -0.30 & 0.75 & -0.57 \\
RCP8.5 & -0.99 & 0.99 & 0.98 & -0.84 & -0.96 & 0.96 & -0.97 \\
\hline
\end{tabular}

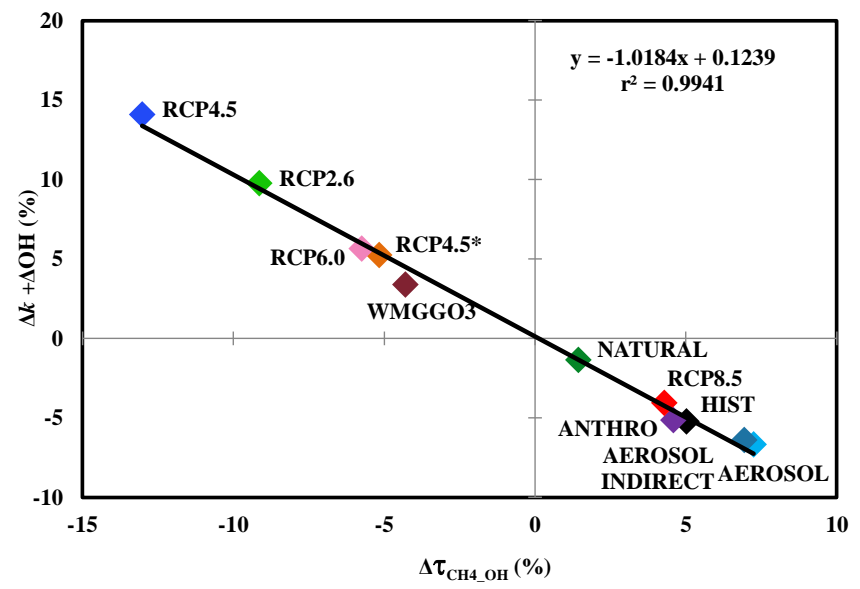

Fig. 2. Percent change in methane lifetime against loss by tropospheric $\mathrm{OH}\left(\Delta \tau_{\mathrm{CH} 4 \text { _OH }}\right)$ versus sum of percent change in rate constant $(\Delta k)$ and $\mathrm{OH}(\Delta \mathrm{OH})$ in $\mathrm{CM} 3 / \mathrm{CMIP} 5$ simulations, using $20 \mathrm{yr}$ averages from 1860-1879 to 1986-2005 for historical simulations, and from 2006-2025 to 2081-2100 for future projections. Colored diamonds: HIST (black), AEROSOL (cyan), AEROSOL INDIRECT (blue), ANTHRO (purple), NATURAL (dark green), WMGGO3 (brown), RCP2.6 (light green), RCP4.5 (dark blue), RCP4.5* (orange), RCP6.0 (pink), RCP8.5 (red).

The "single-forcing" simulations (Table 3) provide additional insights into the relative importance of individual processes in driving the changes in HIST. The lifetime increases in all of the single-forcing simulations, with the exception of WMGGO3 where $\tau_{\text {CH4_OH }}$ decreases by $4.3 \%$ (Table 5 , Fig. 1). The consistency of the overall $\tau_{\mathrm{CH} 4-\mathrm{OH}}$ changes be-

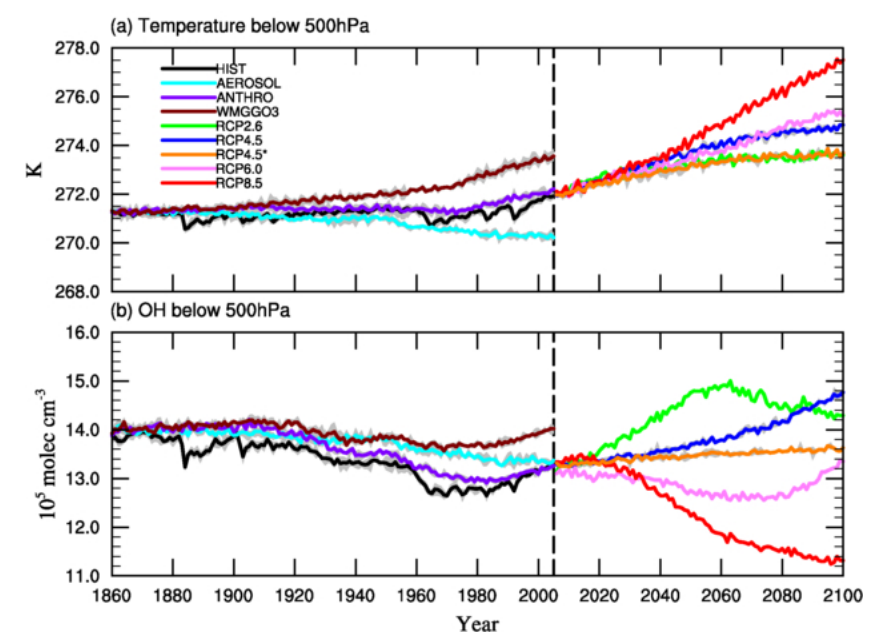

Fig. 3. Trajectories of drivers of methane lifetime against loss by tropospheric $\mathrm{OH}$ in CM3/CMIP5 simulations. Panels show global annual average airmass-weighted (a) temperature below $500 \mathrm{hPa}$ (K) and (b) $\mathrm{OH}$ below $500 \mathrm{hPa}\left(10^{5} \mathrm{molec} \mathrm{cm}^{-3}\right)$. Grey shaded regions indicate the range of ensemble members. Colored lines: HIST (black), AEROSOL (cyan), ANTHRO (purple), WMGGO3 (brown), RCP2.6 (light green), RCP4.5 (dark blue), RCP4.5* (orange), RCP6.0 (pink), RCP8.5 (red).

tween ANTHRO and HIST confirms the dominant role of anthropogenic drivers, as opposed to natural forcings, in shaping the $\tau_{\mathrm{CH} 4-\mathrm{OH}}$ evolution over the historical period. The percent change in the methane loss rate due to the temperature dependence of the reaction rate constant from 1860-1879 to 1986-2005 in ANTHRO is almost double that of HIST 
(1.4\% vs. $0.8 \%$ in Table 5), as there is no cooling effect from volcanoes. Despite this stronger temperature effect on ANTHRO, the percent increase in the lifetime of $\mathrm{CH}_{4}$ is comparable to that of HIST due to an offsetting larger decrease in $\mathrm{OH}$ (Table 5, Fig. 3b). Correlations of $\mathrm{OH}$ with $\mathrm{CO}$ emissions, $\mathrm{CH}_{4}$ and $\mathrm{J}\left(\mathrm{O}^{1} \mathrm{D}\right)$ (Table 6) are stronger in ANTHRO as the "forced" signal in HIST is masked by natural variability (e.g., volcanoes) to some extent. Without the effects of natural forcings, the average $\tau_{\mathrm{CH} 4 . \mathrm{OH}}$ over the period 1860 to 2005 is $2.2 \%$ lower (compare ANTHRO with HIST in Table 4).

The largest increases in $\tau_{\mathrm{CH} 4 \mathrm{OH}}$ from 1860-1879 to 19862005 occur in the AEROSOL and AEROSOL INDIRECT simulations ( $\sim 7 \%$ each in Table 5). These larger increases as compared to HIST are driven entirely by aerosol-induced climate feedbacks on both temperature and $\mathrm{OH}$, with the $\mathrm{OH}$ impact on $\tau_{\text {Сн4-ОН }}$ almost double that of the temperature effect (Table 5). The overall reduction in $\mathrm{OH}$ can be ascribed to climate change in response to aerosol increases over the historical period because the $\mathrm{CH}_{4}$ burden and emissions of $\mathrm{CO}$ and $\mathrm{NO}_{\mathrm{x}}$ are held constant at 1860 values in these simulations (Table 3). OH concentrations in AEROSOL and AEROSOL INDIRECT strongly correlate with lightning $\mathrm{NO}_{\mathrm{x}}$, water vapor and $\mathrm{J}\left(\mathrm{O}^{1} \mathrm{D}\right)$ (all below $500 \mathrm{hPa}$ ) (Table 6). The consistency between the AEROSOL INDIRECT and AEROSOL in the evolution of $\tau_{\mathrm{CH} 4 . \mathrm{OH}}$ (identical correlations of $\tau_{\mathrm{CH} 4 \text { _OH }}$ against temperature and $\mathrm{OH}$ below $500 \mathrm{hPa}$ in Table 4; similar percentage changes in Table 5 and correlations of $\mathrm{OH}$ versus the climate factors in Table 6), imply that aerosol-cloud interactions (indirect effect) dominate the CM3 climate response to aerosols. $\tau_{\mathrm{CH} 4 . \mathrm{OH}}$ in the model is therefore sensitive to the aerosol indirect effect (Unger et al., 2009).

In ANTHRO, aerosol-induced cooling is offset by increases in temperature and $\mathrm{OH}$ associated with rising greenhouse gases (Fig. 3). Indeed, $\tau_{\mathrm{CH} 4 . \mathrm{OH}}$ is considerably decreased in WMGGO3 due to a large warming (Fig. 3a), which leads the percent change in the $\mathrm{CH}_{4}+\mathrm{OH}$ reaction rate constant to increase by factors of about 6 and 3.3, respectively, compared to HIST and ANTHRO (4.6\% vs. $0.8 \%$ and $1.4 \%$ in Table 5). In this ensemble, the changes in $\mathrm{CH}_{4}$ burden, $\mathrm{CO}$ and $\mathrm{NO}_{\mathrm{x}}$ emissions are the same as in HIST and ANTHRO (Tables 3, 5), but rising temperatures ( $2 \mathrm{~K}$ by 2005$)$ and the associated rise in water vapor increase $\mathrm{OH}$ and thus drive $\tau_{\mathrm{CH} 4 . \mathrm{OH}}$ down in WMGGO3 (Table 5), a negative feedback on climate. The single-forcing experiments thus serve to illustrate that the overall changes in HIST and ANTHRO reflect a complex balance among several opposing influences on temperature and $\mathrm{OH}$, both of which determine the overall $\tau_{\mathrm{CH} 4-\mathrm{OH}}$ evolution.

\subsection{Selected periods within the historical simulations}

Although we conclude that $\mathrm{CH}_{4}$ anthropogenic emissions drive the overall changes in $\tau_{\mathrm{CH} 4 . \mathrm{OH}}$ from 1860 to the present, climate feedbacks are evident for specific time periods in HIST. Following volcanic events such as Krakatoa (1883),
Agung (1963), El Chichón (1982) and Pinatubo (1991), methane lifetime peaks (Fig. 1), resulting from strong stratospheric aerosol-induced cooling in the model and the associated decrease in water vapor (Figs. 3a, 4b). OH is reduced as a result of the lower atmospheric humidity, as well as decreases in lightning $\mathrm{NO}_{\mathrm{x}}$ (Fig. 4a); with minima in temperature, $\mathrm{OH}$, water vapor and $\mathrm{LNO}_{\mathrm{x}}$ coinciding with the peak methane lifetimes occurring in 1884, 1965, 1983 and 1992.

In WMGGO3, temperature, together with water vapor, rises gradually before the 1960's and more sharply after. From 1921-1970, increasing $\mathrm{CO}$ emissions, $\mathrm{CH}_{4}$ burden and decreasing photolysis rates drive $\mathrm{OH}$ down, counterbalancing the competing influences of rising temperature, water vapor, $\mathrm{NO}_{\mathrm{x}}$ and $\mathrm{LNO}_{\mathrm{x}}$. In the late 20 th century, $\tau_{\mathrm{CH} 4 \mathrm{OH}}$ falls continuously as temperature and water vapor continue to rise even more rapidly (Figs. 3a, $4 \mathrm{~b}) . \tau_{\mathrm{CH} 4 \text {-Он }}$ is well correlated with OH within time periods (1860-1920, 1921-1970, and 1971-2005), but the different rates of change of temperature and $\mathrm{OH}$ within these time periods results in the lack of correlation over the entire length of the simulation (Table 4). As noted in Sect. 4.1, $\tau_{\text {СН4.ОН }}$ in WMGGO3 is driven mostly by temperature through changes in the rate constant, and associated water vapor.

\subsection{Trends in recent decades}

Over the last $20 \mathrm{yr}$ of HIST $\tau_{\mathrm{CH} 4 . \mathrm{OH}}$ declines steadily, coinciding with the period of most rapid warming, suggesting a negative climate feedback since rising temperature and water vapor shorten $\tau_{\text {СН4-ОН }}$ (Bekki and Law, 1997; Johnson et al., 2002; Dentener et al., 2003; Fiore et al., 2006). Since the 1970 's, we also note an increase in $\mathrm{J}\left(\mathrm{O}^{1} \mathrm{D}\right)$, presumably driven by depletion of stratospheric ozone (Fig. 4c, d) as aerosol changes do not directly affect photolysis rates in these simulations, except through aerosol-induced cloud changes. The increase in $\mathrm{J}\left(\mathrm{O}^{1} \mathrm{D}\right)$ also enhances $\mathrm{OH}$ formation and shortens $\tau_{\text {CH4.OH }}$ (Wang et al., 2004). From 1998$2005, \tau_{\text {СH_-Он }}$ continued to fall as stratospheric $\mathrm{O}_{3}$ and $\mathrm{J}\left(\mathrm{O}^{1} \mathrm{D}\right)$ leveled off, indicating that these factors were not contributing to the $\mathrm{OH}$ changes during this period. Вy $2005, \tau_{\mathrm{CH} 4 . \mathrm{OH}}$ in HIST tracks with ANTHRO, perhaps in part due to the lack of major volcanic eruptions since Pinatubo.

We find a small $(\sim 3 \%)$ increase in modeled $\mathrm{OH}$ over the 1980-2000 period, which is consistent with the multimodel ensemble value of $3.5 \pm 2.2 \%$ reported by Naik et al. (2012b). This small positive $\mathrm{OH}$ trend in recent decades is consistent with the current generation of models (Table 2), but disagrees with the negative $\mathrm{OH}$ trends inferred from observations of $\mathrm{CH}_{3} \mathrm{CCl}_{3}$ and inversion studies (e.g., Prinn et al., 2001; Bousquet et al., 2005). More recently, however, Montzka et al. (2011) suggest that uncertainties in measurements of $\mathrm{CH}_{3} \mathrm{CCl}_{3}$ prior to 1998 may have contributed to the wide $\mathrm{OH}$ variability reported in previous studies; they find a small observationally-derived $\mathrm{OH}$ interannual variability of $2.3 \pm 1.5 \%$ from $1998-2007$. 

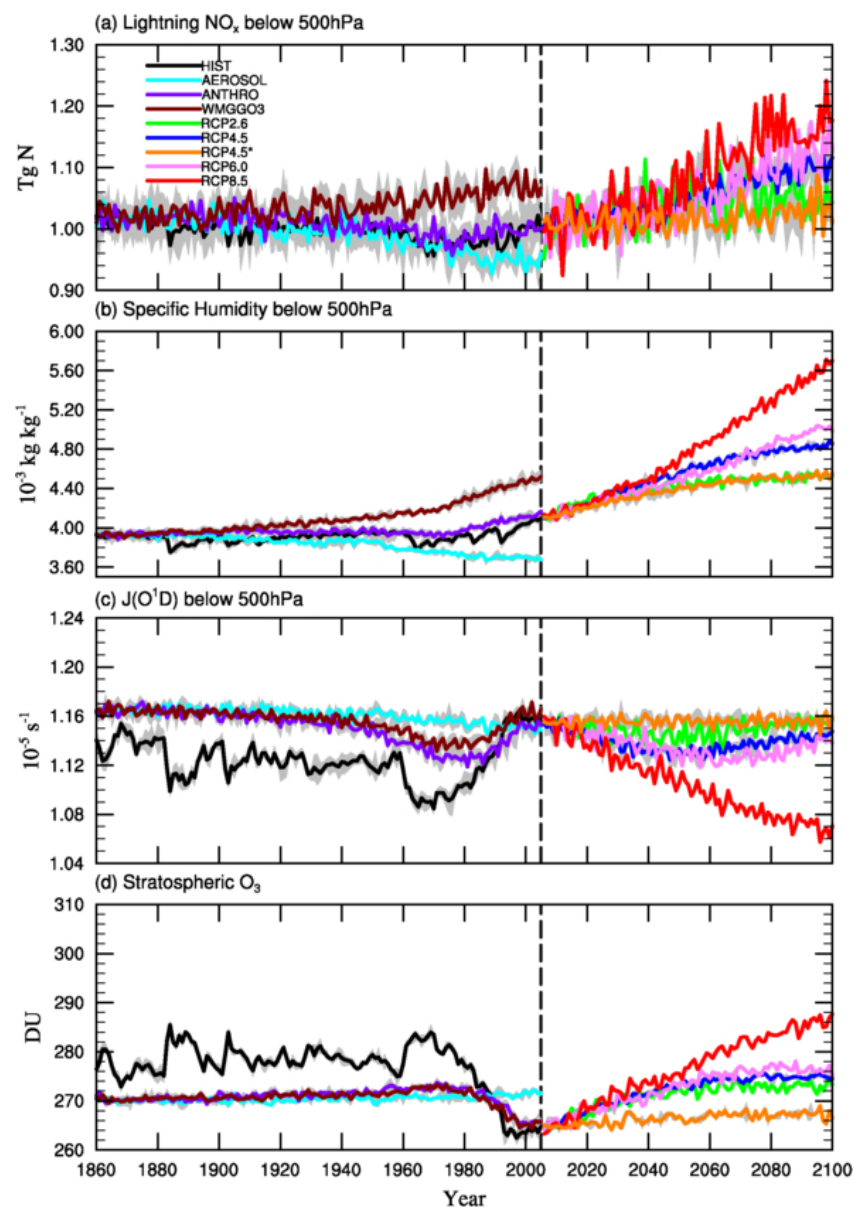

Fig. 4. Evolution of climate drivers of $\mathrm{OH}$ in $\mathrm{CM} 3 / \mathrm{CMIP} 5$ simulations. Panels show (a) global annual total lightning $\mathrm{NO}_{\mathrm{x}}$ $(\mathrm{Tg} \mathrm{N})$, global annual average airmass-weighted (b) specific humidity $\left(\mathrm{H}_{2} \mathrm{O}, 10^{-3} \mathrm{~kg} \mathrm{~kg}^{-1}\right)$ and (c) photolysis rate $\left(\mathrm{J}\left(\mathrm{O}^{1} \mathrm{D}\right)\right.$, $\left.10^{-5} \mathrm{~s}^{-1}\right)$, and (d) global annual total stratospheric ozone (DU). $\mathrm{LNO}_{\mathrm{x}}, \mathrm{H}_{2} \mathrm{O}$ and $\mathrm{J}\left(\mathrm{O}^{1} \mathrm{D}\right)$ are all below $500 \mathrm{hPa}$. Grey shaded regions indicate the range of ensemble members. Colored lines: HIST (black), AEROSOL (cyan), ANTHRO (purple), WMGGO3 (brown), RCP2.6 (light green), RCP4.5 (dark blue), RCP4.5* (orange), RCP6.0 (pink), RCP8.5 (red).

Similar to HIST, $\tau_{\text {Сн4-Он }}$ in ANTHRO continues to fall over the last $20 \mathrm{yr}$, likely reflecting some combination of rising water vapor and an increase in tropical $\mathrm{NO}_{\mathrm{x}}$ emissions, particularly over India and Southeast Asia (not shown; Gupta et al., 1998; Wild and Palmer, 2008). After 1980, increasing temperatures, water vapor and $\mathrm{OH}$ concentrations shorten $\mathrm{CH}_{4}$ lifetime in ANTHRO, while cooling and decreasing $\mathrm{OH}$ in AEROSOL have the opposite effect, causing the lifetime to increase. Stratospheric ozone rises slightly in AEROSOL after 1990, as opposed to the strong decrease in ANTHRO; by $2005 \tau_{\mathrm{CH} 4 . \mathrm{OH}}$ in AEROSOL exceeds that in ANTHRO by $0.42 \mathrm{yr}$ (Fig. 1). After 1985, increased $\mathrm{J}\left(\mathrm{O}^{1} \mathrm{D}\right)$ in WMGGO3, correlated with the depletion of stratospheric ozone, along with rising temperatures and water vapor (Figs. $3 a, 4 b$ ) cause
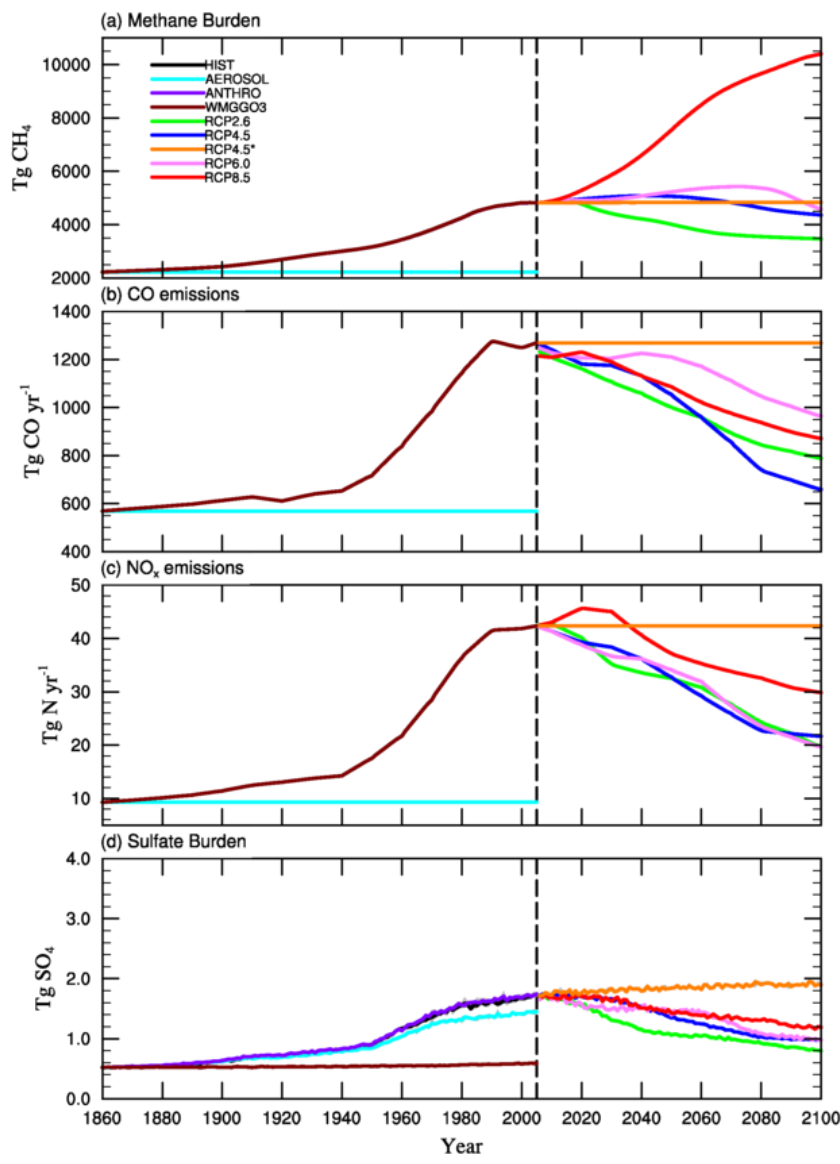

Fig. 5. Evolution of emission/chemistry drivers of $\mathrm{OH}$ in CM3/CMIP5 simulations. Panels show global annual total (a) methane burden $\left(\mathrm{Tg} \mathrm{CH}_{4}\right)$ (b) $\mathrm{CO}$ emissions $\left(\mathrm{Tg} \mathrm{CO} \mathrm{yr}{ }^{-1}\right.$ ) (c) $\mathrm{NO}_{\mathrm{x}}$ emissions $\left(\mathrm{Tg} \mathrm{Nyr}^{-1}\right)$ and (d) sulfate burden $\left(\mathrm{Tg} \mathrm{\textrm {SO } _ { 4 }}\right)$. Grey shaded regions indicate the range of ensemble members. Colored lines: HIST (black), AEROSOL (cyan), ANTHRO (purple), WMGGO3 (brown), RCP2.6 (light green), RCP4.5 (dark blue), RCP4.5* (orange), RCP6.0 (pink), RCP8.5 (red).

$\tau_{\mathrm{CH} 4 \text {-ОH }}$ to decrease steadily as in HIST, for an overall $4 \%$ decline over the period 1971-2005. In all the single-forcing simulations except for AEROSOL and AEROSOL INDIRECT, the climate drivers (rapid warming and associated increase in water vapor) dominate in the late 20th century, and the methane lifetime decreases.

Our historical and single-forcing experiments over the 1860-2005 period illustrate the diverse factors influencing the evolution of the methane lifetime, with cooling from aerosol-cloud interactions masking the effects of greenhouse gas warming over the historical period in CM3. Rising temperatures and increases in water vapor and $\mathrm{LNO}_{\mathrm{x}}$ drive $\tau_{\text {Сн4-Он }}$ down (Tables 4,5 ) in WMGGO3. In contrast, the temperature-driven changes in reaction rate constant, water vapor and lightning $\mathrm{NO}_{\mathrm{x}}$ are of the opposite sign in AEROSOL (Table 5) and $\tau_{\text {СH4.ОН }}$ increases. Both climate and emissions influence the simulated methane lifetime in 
HIST; while emission-driven changes dominate the overall increase in $\tau_{\mathrm{CH} 4 . \mathrm{OH}}$ from the pre-industrial to present, climate warming in the late 20th century shortens the lifetime of $\mathrm{CH}_{4}$. The aerosol indirect effect plays a major role in CM3 and its impacts on changes in methane lifetime need further investigation.

\section{Future scenarios (2006-2100)}

We focus first on the three RCP scenarios (RCP2.6, RCP4.5 and RCP6.0) that have equivalent decreases in anthropogenic $\mathrm{NO}_{\mathrm{x}}$ emissions $(\sim 45 \%)$ by the end of the century (Table 5 ). The trajectory of $\tau_{\text {СH4.ОH }}$ in RCP2.6 (Fig. 1) initially drops, reaching a minimum value of $7.22 \mathrm{yr}$ in 2063 , after which it rebounds, for an overall 9.1\% decrease from 2006-2025 to 2081-2100. In this "low warming" scenario, the associated temperature change below $500 \mathrm{hPa}$ over the same time periods is $\sim 1.1 \mathrm{~K}$, while lower tropospheric $\mathrm{OH}$ increases by $7.3 \%$ (Table 5, Fig. 3), with both factors contributing to the decrease in $\tau_{\mathrm{CH} 4 \text {.Он }}$. The increase in $\mathrm{OH}$ concentration reflects increases in water vapor, lightning $\mathrm{NO}_{\mathrm{x}}$, and $\mathrm{J}\left(\mathrm{O}^{1} \mathrm{D}\right)$, and is further enhanced by reductions in $\mathrm{CH}_{4}$ burden and $\mathrm{CO}$ emissions (Table 5), which together outweigh the $46 \%$ reduction in total $\mathrm{NO}_{\mathrm{x}}$ emissions. Prior to 2063, OH rises rapidly, driven by almost linear declines in methane burden and $\mathrm{CO}$ emissions (Fig. 5a, b). After 2063, $\tau_{\mathrm{CH} 4-\mathrm{OH}}$ increases as the evolution of $\mathrm{OH}$ reverses and starts decreasing, driven by declining anthropogenic $\mathrm{NO}_{\mathrm{x}}$ emissions, which offset the combined impacts on $\mathrm{OH}$ from warming and declining anthropogenic $\mathrm{CO}$ emissions.

Under the moderate warming scenario, RCP4.5, there is a linear decline in the lifetime of methane, which drops by $13 \%$ from $2006-2025$ to $2081-2100$, the largest overall decrease in methane lifetime in any of the RCP projections (Fig. 1). Although the decrease in methane burden is only one-third that in RCP2.6 (Table 5), the larger increases in water vapor and lightning $\mathrm{NO}_{\mathrm{x}}$ (driven by warming which is twice as large in RCP4.5 as compared to RCP2.6) combined with a larger decrease in $\mathrm{CO}$ emissions lead to an overall larger $\mathrm{OH}$ change by the end of the century than in RCP2.6. The overall warming in RCP4.5 is closer to that in RCP6.0 but the $\mathrm{OH}$ change in RCP4.5 is closer to that in RCP2.6, illustrating the complex interplay of climate and emissions in determining methane lifetimes.

We next explore the role of short-lived aerosol and ozone precursors in contributing to the climate-driven changes by comparing RCP4.5 with RCP4.5* (where the short-lived species are held at 2005 levels (Fig. 5), as are $\mathrm{CH}_{4}, \mathrm{~N}_{2} \mathrm{O}$ and ODS for chemistry, but well-mixed radiative greenhouse gases follow the RCP4.5 scenario, Table 3). In RCP4.5*, we again find a decrease in $\tau_{\mathrm{CH} 4 . \mathrm{OH}}$, but the percent change (5\%) is not as large as in the RCP4.5 ensemble - here roughly equal percent changes in rate constant and $\mathrm{OH}$ contribute to a $5 \%$ reduction in methane lifetime (Table 5). Increases in temper- ature, water vapor and lightning $\mathrm{NO}_{\mathrm{x}}$ enhance $\mathrm{OH}$ concentrations, and reduce $\tau_{\mathrm{CH} 4 \mathrm{OH}}$ in the model. We note that the evolution of temperature is very similar in the RCP2.6 and RCP4.5* simulations (Fig. 3a), as more warming from increasing $\mathrm{CO}_{2}$ concentrations in RCP4.5* offsets the aerosol cooling, which has been reduced dramatically (i.e., a warming effect) as sulfate aerosols are considerably decreased in RCP2.6 (e.g., Fig. 4d). Around 2035, the temperatures in RCP4.5 separate from RCP4.5*, and by 2100 are warmer by $1.1 \mathrm{~K}$, illustrating that decreasing aerosols can accelerate warming (e.g., Levy et al., 2008; Raes and Seinfeld, 2009; Makkonen et al., 2012). In addition, the decreases in $\mathrm{CH}_{4}$ and $\mathrm{CO}$ further reinforce the climate-driven decrease in $\tau_{\mathrm{CH} 4 . \mathrm{OH}}$ in RCP4.5 (Table 5).

In the RCP6.0 scenario $\tau_{\mathrm{CH} 4 . \mathrm{OH}}$ also decreases, by $5.2 \%$ from 2006-2025 to 2081-2100 (Table 5). Although the temperature, water vapor, and lightning $\mathrm{NO}_{\mathrm{x}}$ increases are about 2.5 times greater than in RCP2.6, and both RCP2.6 and RCP6.0 have similar $(\sim 45 \%)$ reductions in $\mathrm{NO}_{\mathrm{x}}$ emissions, there is a smaller decrease in CO emissions in RCP6.0 (18\% vs. $31 \%$ ), and the total $\mathrm{CH}_{4}$ burden increases in RCP6.0 (Table 5), leading to an overall reduction in $\mathrm{OH}$, and a longer average $\tau_{\text {Сн4_Он }}$ than in RCP2.6 (8.44 vs. $7.72 \mathrm{yr}$ in Table 4). $\mathrm{OH}$ decreases from 2006 to the mid 2060's and then rises fairly rapidly until 2100 (Fig. 3b). The latter part of this simulation resembles the last quarter century of WMGGO3 in the CM3 model, in so far as rising temperatures and increased $\mathrm{OH}$ (from increasing water vapor, lightning $\mathrm{NO}_{\mathrm{x}}$ and photolysis), contribute to a steady decline in $\tau_{\mathrm{CH} 4 . \mathrm{OH}}$.

RCP8.5 is the most extreme warming scenario, with lower tropospheric temperatures warming by $4.5 \mathrm{~K}$ from 2006 to 2100 in CM3 (Fig. 3a, Table 5). Despite the increasing temperature and humidity (Figs. 3a, 4b), which our previous analysis indicates should shorten the methane lifetime against loss by tropospheric $\mathrm{OH}, \tau_{\mathrm{CH} 4-\mathrm{OH}}$ increases, from $8.24 \mathrm{yr}$ in $2006-2025$ to $8.73 \mathrm{yr}$ in $2081-2100$, with a peak value of $8.91 \mathrm{yr}$ in 2062 (Fig. 1). This increase in lifetime is due to a decrease in $\mathrm{OH}$ beginning after 2035, with an overall $14.8 \%$ reduction by the end of the century (Fig. 3b, Table 5). The near doubling of $\mathrm{CH}_{4}$ abundance by 2100 (Table 5) depletes $\mathrm{OH}$ and leads to a positive feedback on the climate system, as concentrations of $\mathrm{CH}_{4}$ increase further (Prather, 1994). The rise in anthropogenic $\mathrm{CH}_{4}$ outweighs the climate-driven changes which act to shorten the methane lifetime (Table 5, Figs. 3a, 4a, b, 5a), viz.: rising temperature, water vapor, lightning $\mathrm{NO}_{\mathrm{x}}$. In the late 21 st century $\tau_{\text {сн4-ОН }}$ declines slightly, presumably reflecting the negative feedback from climate.

\section{Conclusions}

Improved understanding of feedbacks between $\mathrm{CH}_{4}$ abundances and the climate system are important as they impact not only climate, but also the environment and human health. 
The relatively short lifetime of methane makes it a suitable candidate for mitigation efforts, as reducing $\mathrm{CH}_{4}$ emissions decreases radiative forcing and improves global air quality (e.g., Fiore et al., 2002; Shindell et al., 2012). Understanding the processes driving the trends and variability in methane lifetime is a crucial step towards accurately projecting its future evolution.

We used a suite of CM3 model simulations to evaluate the role of climate and emissions in determining methane lifetime against loss by tropospheric $\mathrm{OH},\left(\tau_{\mathrm{CH} 4-\mathrm{OH}}\right)$, and to pinpoint key drivers from the preindustrial period to the end of the 21 st century. Over the historical period, the $\tau_{\text {сн4.ОН }}$ increases by $5 \%$ overall due to anthropogenic emission increases in $\mathrm{CH}_{4}$ offsetting increases in $\mathrm{OH}$ from increased $\mathrm{NO}_{\mathrm{x}}$ emissions and from climate warming. There are also indications of climatically-driven intervals, e.g., after volcanic events when cooling by aerosols causes the methane lifetime to rise (e.g., HIST in Figs. 1, 3a). During the late 20 th century, $\tau_{\mathrm{CH} 4 . \mathrm{OH}}$ decreases steadily as rapid warming occurs, and the observed leveling off in atmospheric $\mathrm{CH}_{4}$ during that time could partially reflect climate-driven influences on the methane sink in addition to increases in tropical anthropogenic $\mathrm{NO}_{\mathrm{x}}$ emissions. We find a small $\mathrm{OH}$ increase (3\%) in recent decades (1980-2000), consistent with previous model studies. While earlier observation-based analyses indicated large decreasing trends in $\mathrm{OH}$ over this period (Prinn et al., 2005), Montzka et al. (2011) show that the measurements are much more variable prior to 1998 , potentially confounding estimates of trends in $\mathrm{OH}$.

Projected changes in $\tau_{\mathrm{CH} 4 . \mathrm{OH}}$ for the 21 st century are: $-9 \%$, $-13 \%,-6 \%$, and $+4 \%$ for RCP2.6, RCP 4.5 , RCP 6.0 , and RCP8.5, respectively (changes are 2081-2100 average minus 2006-2025 average). Assuming soil, stratospheric and tropospheric chlorine sinks $(120,150$, and $200 \mathrm{yr}$, respectively) remain constant, projected changes in total methane lifetime are $-12 \%$ (RCP2.6), $-15 \%$ (RCP4.5), $-7 \%$ (RCP6.0) and $-0.3 \%$ (RCP8.5). The large increases in $\mathrm{CH}_{4}$ outweigh the extreme warming in the RCP8.5 scenario, and results in the projected increase in $\tau_{\text {Сн4.ОН }}$. We also find positive feedbacks on the climate system; in $\mathrm{RCP} 8.5$, the additional $\mathrm{CH}_{4}$ and other emission changes increase the methane lifetime (despite the tendency of warmer climate to reduce $\tau_{\text {сн4-ОН }}$ ), and amplify climate forcing. Climate and thereby $\tau_{\mathrm{CH} 4-\mathrm{OH}}$ is sensitive to the representation of the aerosol indirect effect in the CM3 model and represents a major source of uncertainty.

In a simulation in which only greenhouse gas radiative forcing evolves following the RCP4.5 pathway (viz.: $\left.\mathrm{RCP} 4.5^{*}\right)$, rising temperatures and enhanced $\mathrm{OH}$ shorten $\tau_{\mathrm{CH} 4 \text {-ОН }}$. Decreases in aerosol, $\mathrm{CO}$ and $\mathrm{CH}_{4}$ in the full RCP4.5 scenario augment these climate-driven changes to further decrease $\tau_{\mathrm{CH} 4 \mathrm{OH}}$. Combining the sensitivities from Table 2 of Holmes et al. (2012) with our percentage changes in Table 5 suggests that water vapor is a stronger influence on $\tau_{\mathrm{CH} 4 . \mathrm{OH}}$ than $\mathrm{LNO}_{\mathrm{x}}$ (both are responding to temperature changes), but the large uncertainties surrounding $\mathrm{LNO}_{\mathrm{x}}$ parameterizations (e.g., Labrador et al., 2004, 2005) and their impact on $\mathrm{OH}$ requires further study.

Ongoing efforts such as the Atmospheric Chemistry and Climate Model Intercomparison Project (Lamarque et al., 2012) provide opportunities to further explore and evaluate the role of climate versus emission-driven changes in determining the trends and variability in the lifetime of methane (Naik et al., 2012b; Voulgarakis et al., 2012). Together, these results provide a benchmark for future analyses of methane lifetime in chemistry-climate models. Future efforts should consider the feedbacks to $\mathrm{CH}_{4}$ from wetlands as well as other emissions from the biosphere (biogenic $\mathrm{VOC}$ and $\mathrm{NO}_{\mathrm{x}}$; wildfires), and any changes in the soil and stratospheric sinks. For example, wetland emissions are expected to increase with warming (e.g., O'Connor, 2010) and the net impact of this positive feedback and the negative climate feedbacks (from water vapor, $\mathrm{LNO}_{\mathrm{x}}$ ) found here should be assessed. Reducing the uncertainty in the contemporary global methane budget would help build confidence in future projections of the $\mathrm{CH}_{4}$ response to climate change. In particular, process-based approaches, including new global scale satellite observations (e.g., Bloom et al., 2010 for wetlands) should help to elucidate the mechanisms determining atmospheric abundances of methane and $\mathrm{OH}$.

Acknowledgements. We thank Hiram Levy and Songmiao Fan for insightful suggestions and comments on the manuscript, and Keith Dixon for suggestions on presentation of Tables 5 and 6 in black and white.

Edited by: M. K. Dubey

\section{References}

Allan, W., Struthers, H., and Lowe, D. C.: Methane carbon isotope effects caused by atomic chlorine in the marine boundary layer: Global model results compared with Southern Hemisphere measurements, J. Geophys. Res., 112, D04306, doi:10.1029/2006JD007369, 2007.

Austin, J. and Wilson, R. J.: Ensemble simulations of the decline and recovery of stratospheric ozone, J. Geophys. Res., 111, D16314, doi:10.1029/2005JD006907, 2006.

Austin, J. and Wilson, R. J.: Sensitivity of polar ozone to sea surface temperatures and halogen amounts, J. Geophys. Res., 115, D18303, doi:10.1029/2009JD013292, 2010.

Aydin, M., Verhulst, K. R., Saltzmann, E. S., Battle, M. O., Montzka, S. A., Blake, D. R., Tang, Q., and Prather, M. J.: Recent decreases in fossil-fuel emissions of ethane and methane derived from firn air, Nature, 476, 198-201, doi:10.1038/nature10352, 2011.

Bekki, S. and Law, K. S.: Sensitivity of the atmospheric $\mathrm{CH}_{4}$ growth rate to global temperature changes observed from 1980 to 1992 , Tellus, 49, 409-416, 1997.

Berntsen, T. K., Isaksen, I. S. A., Myhre, G., Fuglestvedt, J. S., Stordal, F., Larsen, T. A., Freckleton, R. S., and Shine, K. P.: Effects of anthropogenic emissions on tropospheric ozone 
and its radiative forcing, J. Geophys. Res., 102, 28101-28126, doi:10.1029/97JD02226, 1997.

Bloom, A. A., Palmer, P. I., Fraser, A., Reay, D. S., and Frankenberg, C.: Large-Scale Controls of Methanogenesis Inferred from Methane and Gravity Spaceborne Data, Science, 327, 322-325, 2010.

Bousquet, P., Hauglustaine, D. A., Peylin, P., Carouge, C., and Ciais, P.: Two decades of $\mathrm{OH}$ variability as inferred by an inversion of atmospheric transport and chemistry of methyl chloroform, Atmos. Chem. Phys., 5, 2635-2656, doi:10.5194/acp-52635-2005, 2005.

Bousquet, P., Ciais, P., Miller, J. B., Dlugokencky, E. J., Hauglustaine, D. A., Prigent, C., Van der Werf, G. R., Peylin, P., Brunke, E. G., Carouge, C., Langenfels, R. L., Lathiere, J., Papa, F., Ramonet, M., Schmidt, M., Steele, L. P., Tyler, S. C., and White, J.: Contribution of anthropogenic and natural sources to atmospheric methane variability, Nature, 443, 439-443, 2006.

Brasseur, G. J., Kiehl, T., Muller, J. F., Schneider, T., Granier, C., Tie, X. X., and Hauglustaine, D.: Past and future changes in global tropospheric ozone: Impact on radiative forcing, Geophys. Res. Lett., 25, 3807-3810, 1998.

Crutzen, P. J. and Zimmermann, P. H.: The changing photochemistry of the troposphere, Tellus, 43, 136-151, 1991.

Crutzen, P. J., Lawrence, M. G., and Pöschl, U.: On the background photochemistry of tropospheric ozone, Tellus, 51, 123146, 1999.

Dalsøren, S. B. and Isaksen, I. S. A.: CTM study of changes in tropospheric hydroxyl distribution 1990-2001 and its impact on methane, Geophys. Res. Lett., 33, L23811, doi:10.1029/2006GL027295, 2006.

Denman, K. L., Brasseur, G., Chidthaisong, A., Ciais, P., Cox, P. M., Dickenson, R. E., Hauglustaine, D., Heinze, C., Holland, E., Jacob, D. J., Lohmann, U., Ramachandran, S., da Silva Dias, P. L., Wofsy, S. C., and Zhang, X.: Couplings between changes in the climate system and biogeochemistry, in: Climate Change 2007: The Physical Science Basis. Contribution of Working Group I to the Fourth Assessment Report of the Intergovernmental Panel on Climate Change, edited by: Solomon, S., Qin, D., Manning, M., Chen, Z., Marquis, M., Averyt, K. B., Tignor, M., and Miller, H. L., Cambridge University Press, Cambridge, United Kingdom and New York, NY, USA, 499-587, 2007.

Dentener, F., Peters, W., Krol, M., Van Weele, M., Bergamaschi, P., and Lelieveld, J.: Interannual variability and trend of $\mathrm{CH}_{4}$ lifetime as a measure for OH changes in the 1979-1993 time period, J. Geophys. Res., 108, 4442, doi:10.1029/2002JD002916, 2003.

Dlugokencky, E. J., Masarie, K. A., Lang, P. M., and Tans, P. P.: Continuing decline in the growth rate of the atmospheric methane burden, Nature, 393, 447-450, 1998.

Dlugokencky, E. J., Houweling, S., Bruhwiler, L., Masarie, K. A., Lang, P. M., Miller, J. B., and Tans, P. P.: Atmospheric methane levels off: Temporary pause or a new steady-state?, Geophys. Res. Lett., 30, 1992, doi:10.1029/2003GL018126, 2003.

Dlugokencky, E. J., Bruhwiler, L., White, J. W. C., Emmons, L. K., Novelli, P. C., Montzka, S. A., Masarie, K. A., Lang, P. M., Crotwell, A. M., Miller, J. B., and Gatti, L. V.: Observational constraints on recent increases in the atmospheric $\mathrm{CH}_{4}$ burden, Geophys. Res. Lett., 36, L18803, doi:10.1029/2009GL039780, 2009.
Donner, L. J., Wyman, B. L., Hemler, R. S., Horowitz, L. W., Ming, Y., Zhoa, M., Golaz, J.-C., Ginoux, P., Lin, S.-J., Schwarkopf, M. D., Austin, J., Alaka, G., Cooke, W. F., Delworth, T. L., Freidenreich, S. M., Gordon, C. T., Griffies, S. M., Held, I. M., Hurlin, W. J., Klein, S. A., Knutson, T. R., Langenhorst, A. R., Lee, H.C., Lin, Y., Magi, B. I., Malyshev, S. L., Milly, P. C. D., Naik, V., Nath, M. J., Pincus, R., Ploshay, J. J., Ramaswamy, V., Seman, C. J., Shevliakova, E., Sirutis, J. J., Stern, W. F., Stouffer, R. J., Stouffer, R. J., Wilson, R. J., Winton, M., Wittenberg, A. T., and Zeng, F.: The dynamical core, physical parameterizations, and basic simulation characteristics of the atmospheric component AM3 of the GFDL Global Coupled Model CM3, J. Climate, 24, 3484-3519, 2011.

Fiore, A. M., Jacob, D. J., Field, B. D., Streets, D. G., Fernandes, S. D., and Jang, C.: Linking ozone pollution and climate change: The case for controlling methane, Geophys. Res. Lett., 29, 1919, doi:10.1029/2002GL015601, 2002.

Fiore, A. M., Horowitz, L. W., Dlugokencky, E. J., and West, J. J.: Impact of meteorology and emissions on methane trends, 1990-2004, Geophys. Res. Lett., 33, L12809, doi:10.1029/2006GL026199, 2006.

Fiore, A. M., West, J. J., Horowitz, L. W., Naik, V., and Schwarzkopf, M. D.: Characterizing the tropospheric ozone response to methane emission controls and the benefits to climate and air quality, J. Geophys. Res., 113, D08307, doi:10.1029/2007JD009162, 2008.

Fiore, A. M., Dentener, F. J., Wild, O., Cuvelier, C., Schultz, M. G., Hess, P., Textor, C., Schulz, M., Doherty, R. M., Horowitz, L. W., MacKenzie, I. A., Sanderson, M. G., Shindell, D. T., Stevenson, D. S., Szopa, S., Van Dingenen, R., Zeng, G., Atherton, C., Bergmann, D., Bey, I., Carmichael, G., Collins, W. J., Duncan, B. N., Faluvegi, G., Folberth, G., Gauss, M., Gong, S. L, Hauglustaine, D., Holloway, T., Isaksen, I. S. A., Jacob, D. J., Jonson, J. E., Kaminski, J. W., Keating, T. J., Lupu, A., Marmer, E., Montanaro, V., Park, R. J., Pitari, G., Pringle, K. J., Pyle, J.A., Schroeder, S., Vivanco, M. G., Wind, P., Wojcik, G., Wu, S., and Zuber, A.: Multimodel estimates of intercontinental sourcereceptor relationships for ozone pollution, J. Geophys. Res., 114, D04301, doi:04310.01029/02008JD010816, 2009.

Forster, P., Ramaswamy, V., Artaxo, P., Berntsen, T., Betts, R., Fahey, D. W., Haywood, J., Lean, J., Lowe, D. C., Myhre, G., Nganga, J., Prinn, R., and Raga, G., Schulz, M., and Van Dorland, R.: Changes in Atmospheric Constituents and in Radiative Forcing, in: Climate Change 2007: The Physical Science Basis, Contribution of Working Group I to the Fourth Assessment Report of the Intergovernmental Panel on Climate Change, edited by: Solomon, S., Qin, D., Manning, M., Chen, Z., Marquis, M., Averyt, K. B., Tignor, M., and Miller, H. L., Cambridge University Press, Cambridge, United Kingdom and New York, NY, USA, 129-234, 2007.

Grenfell, J. L., Shindell, D. T., Koch, D., and Rind, D.: Chemistryclimate interactions in the Goddard Institute general circulation model 2, New insights into modeling the pre-industrial atmosphere, J. Geophys. Res., 106, 33435-33451, 2001.

Griffies, S. M, Winton, M., Donner, L. J., Horowitz, L. W., Downes, S. M., Farneti, R., Gnanadesikan, A., Hurlin, W. J., Lee, H.C., Liang, Z., Palter, J. B., Samuels, B. L., Wittenberg, A. T., Wyman, B. L., Yin, J., and Zadeh, N.: The GFDL CM3 coupled climate model: Characteristics of the ocean and sea ice simula- 
tions, J. Climate, 24, 3520-3544, 2011.

Gupta, M. L., Cicerone, R. J., and Elliot, S.: Perturbation to global tropospheric oxidizing capacity due to latitudinal redistribution of surface sources of $\mathrm{NO}_{\mathrm{x}}, \mathrm{CH}_{4}$ and $\mathrm{CO}$, Geophys. Res. Lett., 25, 3931-3934, 1998.

Hamilton, K. and Fan, S.-M.: Effects of the stratospheric quasibiennial oscillation on long-lived greenhouse gases in the atmosphere, J. Geophys. Res., 105, 20581-20587, 2000.

Hauglustaine, D. A. and Brasseur, G. P.: Evolution of tropospheric ozone under anthropogenic activities and associated radiative forcing of climate, J. Geophys. Res., 106, 32337-32360, doi:10.1029/2001JD900175, 2001.

Hodson, E. L., Poulter, B., Zimmermann, N. E., Prigent, C., and Kaplan, J. O.: The El Niño - Southern Oscillation and wetland methane interannual variability, Geophys. Res. Lett., 38, L08810, doi:10.1029/2011GL046861, 2011.

Holmes, C. D., Prather, M. J., Søvde, O. A., and Myhre, G.: Future methane, hydroxyl, and their uncertainties: key climate and emission parameters for future predictions, Atmos. Chem. Phys. Discuss., 12, 20931-20974, doi:10.5194/acpd-12-20931-2012, 2012.

Horowitz, L. W.: Past, present, and future concentrations of tropospheric ozone and aerosols: methodology, ozone evaluation and sensitivity to aerosol wet removal, J. Geophys. Res., 111, D22211, doi:10.1029/2005JD006937, 2006.

Horowitz, L. W., Walters, S., Mauzerall, D. L., Emmons, L. K., Rasch, P. J., Granier, C., Tie, X., Lamarque, J.-F., Schultz, M. G., Tyndall, G. S., Orlando, J. J., and Brasseur, G. P.: A global simulation of tropospheric ozone and related tracers: description and evaluation of MOZART, version 2, J. Geophys. Res., 108, 4784, doi:10.1029/2002JD002853, 2003.

Johnson, C. E., Stevenson, D. S., Collins, W. J., and Derwent, R. G.: Interannual variability in methane growth rate simulated with a coupled ocean-atmosphere chemistry model, Geophys. Res. Lett., 29, 1903, doi:10.1029/2002GL015269, 2002.

Kai, F. M., Tyler, S. C., Randerson, J. T., and Blake, D. R.: Reduced methane growth rate explained by decreased Northern Hemisphere microbial sources, Nature, 476, 194-197, 2011.

Karlsdóttir, S. and Isaksen, I. S. A.: Changing methane lifetime: Possible cause for reduced growth, Geophys. Res. Lett., 27, 93 96, 2000.

Krol, M., van Leeuwen, P. J., and Lelieveld, J.: Global OH trend inferred from methyl-chloroform measurements, J. Geophys. Res., 103, 10697-10711, 1998.

Labrador, L. J., von Kuhlmann, R., and Lawrence, M. G.: Strong sensitivity of the global mean $\mathrm{OH}$ concentration and the tropospheric oxidizing efficiency to the source of $\mathrm{NO}_{\mathrm{x}}$ from lightning, Geophys. Res. Lett., 31, L06102, doi:10.1029/2003GL019229, 2004.

Labrador, L. J., von Kuhlmann, R., and Lawrence, M. G.: The effects of lightning-produced $\mathrm{NO}_{\mathrm{x}}$ and its vertical distribution on atmospheric chemistry: sensitivity simulations with MATCHMPIC, Atmos. Chem. Phys., 5, 1815-1834, doi:10.5194/acp-51815-2005, 2005.

Lamarque, J.-F., Hess, P., Emmons, L., Buja, L., Washington, W., and Granier, C.: Tropospheric ozone evolution between 1890 and 1990, J. Geophys. Res., 110, D08304, doi:10.1029/2004JD005537, 2005.
Lamarque, J.-F., Bond, T. C., Eyring, V., Granier, C., Heil, A., Klimont, Z., Lee, D., Liousse, C., Mieville, A., Owen, B., Schultz, M. G., Shindell, D., Smith, S. J., Stehfest, E., Van Aardenne, J., Cooper, O. R., Kainuma, M., Mahowald, N., McConnell, J. R., Naik, V., Riahi, K., and van Vuuren, D. P.: Historical (1850-2000) gridded anthropogenic and biomass burning emissions of reactive gases and aerosols: methodology and application, Atmos. Chem. Phys., 10, 7017-7039, doi:10.5194/acp10-7017-2010, 2010.

Lamarque, J.-F., Shindell, D. T., Josse, B., Young, P. J., Cionni, I., Eyring, V., Bergmann, D., Cameron-Smith, P., Collins, W. J., Doherty, R., Dalsoren, S., Faluvegi, G., Folberth, G., Ghan, S. J., Horowitz, L. W., Lee, Y. H., MacKenzie, I. A., Nagashima, T., Naik, V., Plummer, D., Righi, M., Rumbold, S., Schulz, M., Skeie, R. B., Stevenson, D. S., Strode, S., Sudo, K., Szopa, S., Voulgarakis, A., and Zeng, G.: The Atmospheric Chemistry and Climate Model Intercomparison Project (ACCMIP): overview and description of models, simulations and climate diagnostics, Geosci. Model Dev. Discuss., 5, 2445-2502, doi:10.5194/gmdd5-2445-2012, 2012.

Law, K. S. and Nisbet, E. G.: Sensitivity of the methane growth rate to changes in methane emissions from natural gas and coal, J. Geophys. Res., 101, 14387-14397, 1996.

Lawrence, M. G., Jöckel, P., and von Kuhlmann, R.: What does the global mean $\mathrm{OH}$ concentration tell us?, Atmos. Chem. Phys., 1, 37-49, doi:10.5194/acp-1-37-2001, 2001.

Lelieveld, J., Crutzen, P. J., and Dentener, F. J.: Changing concentration, lifetime and climate forcing of atmospheric methane, Tellus, 50, 128-150, 1998.

Lelieveld, J., Peters, W., Dentener, F. J., and Krol, M. C.: Stability of tropospheric hydroxyl chemistry, J. Geophys. Res., 107, 4715, doi:10.1029/2002JD002272, 2002.

Lelieveld, J., Dentener, F. J., Peters, W., and Krol, M. C.: On the role of hydroxyl radicals in the self-cleansing capacity of the troposphere, Atmos. Chem. Phys., 4, 2337-2344, doi:10.5194/acp4-2337-2004, 2004.

Levy, H.: Normal atmosphere: Large radical and formaldehyde concentrations predicted, Science, 173, 141-143, 1971.

Levy, H., Moxim, W. J., and Kasibhatla, P. S.: A global threedimensional time-dependent lightning source of tropospheric $\mathrm{NO}_{\mathrm{x}}$, J. Geophys. Res., 101, 22911-22922, 1996.

Levy, H., Schwarzkopf, M. D., Horowitz, L., Ramaswamy, V., and Findell, K. L.: Strong sensitivity of late 21 st century climate to projected changes in short-lived air pollutants, J. Geophys. Res., 113, D06102, doi:10.1029/2007JD009176, 2008.

Logan, J. A., Prather, M. J., Wofsy, S. C., and McElroy, M. B.: Tropospheric Chemistry: A global perspective, J. Geophys. Res., 86, 7210-7254, 1981.

Makkonen, R., Asmi, A., Kerminen, V.-M., Boy, M., Arneth, A., Hari, P., and Kulmala, M.: Air pollution control and decreasing new particle formation lead to strong climate warming, Atmos. Chem. Phys., 12, 1515-1524, doi:10.5194/acp-12-15152012, 2012.

Martinerie, P., Brasseur, G. P., and Granier, C.: The chemical composition of ancient atmospheres: A model study constrained by ice core data, J. Geophys. Res., 100, 14291-14304, 1995.

Meinshausen, M., Smith, S. J., Calvin, K., Daniel, J. S., Kainuma M. L. T., Lamarque, J.-F., Matsumoto, K., Montzka, S. A., Raper, S. C. B., Riahi, K., Thomson, A., Velders, G. J. M., and van 
Vuuren, D. P. P.: The RCP greenhouse gas concentrations and their extensions from 1765 to 2300, Clim. Change, 109, 213241, doi:10.1007/s10584-011-0156-z, 2011.

Mickley, L. J., Murti, P. P., Jacob, D. J., Logan, J. A., Koch, D. M., and Rind, D.: Radiative forcing from tropospheric ozone calculated with a unified chemistry climate model, J. Geophys. Res., 104, 30153-30172, 1999.

Montzka, S. A., Krol, M., Dlugokencky, E., Hall, B., Jöckel, P., and Lelieveld, J.: Small interannual variability of global atmospheric hydroxyl, Science, 331, 67-69, doi:10.1126/science.1197640, 2011.

Moss, R. H., Edmonds, J. A., Hibbard, K. A., Manning, M. R., Rose, S. K., van Vuuren, D. P., Carter, T. R., Emori, S., Kainuma, M., Kram, T., Meehl, G. A., Mitchell, J. F. B., Nakicenovic, N., Riahi, K., Smith, S. J., Stouffer, R. J., Thomson, A. M., Weyant, J. P., and Wilbanks, T. J.: The next generation of scenarios for climate change research and assessment, Nature, 463, 747-756, doi:10.1038/nature08823, 2010.

Naik, V., Horowitz, L. W., Fiore, A. M., Ginoux, P., Mao, J., Aghedo, A., and Levy, H: Preindustrial to present day impact of changes in short-lived pollutant emissions on atmospheric composition and climate forcing, J. Geophys. Res., in review, 2012a.

Naik, V., Voulgarakis, A., Fiore., A. M., Horowitz, L. W., Lamarque, J.-F., Lin, M., Prather, M. J., Young, P. J., Bergmann, D., Cameron-Smith, P. J., Cionni, I., Collins, W. J., Dalsøren, S., Doherty, R., Eyring, V., Faluvegi, G., Folberth, G. A., Josse, B., Lee, Y. H., McKenzie, I., A., Nagashima, T., van Noije, T. P. C., Plummer, D. A., Righi, M., Rumbold, S. T., Skeie, R., Shindell, D. T., Stevenson, D. S., Strode, S., Sudo., K., Szopa, S., and Zeng, G.: Preindustrial to present day changes in tropospheric hydroxyl radical and methane lifetime from the Atmospheric Chemistry and Climate Model Intercomparison Project (ACCMIP), Atmos. Chem. Phys., 12, 30755-30804, 2012b,

http://www.atmos-chem-phys.net/12/30755/2012/.

O’Connor, F. M., Boucher, O., Gedney, N., Jones, C. D., Folberth, G. A., Coppell, R., Friedlingstein, P., Collins, W. J., Chappellaz, J., Ridley, J., and Johnson, C. E.: Possible role of wetlands, permafrost, and methane hydrates in the methane cycle under future climate change, a review, Rev. Geophys., 48, RG4005, doi:10.1029/2010RG000326, 2010.

Osborn T. J. and Wigley, T. M. L.: A simple model for estimating methane concentration and lifetime variations, Clim. Dynam., 9, 181-193, 1994.

Prather, M. J.: Lifetimes and eigenstates in atmospheric chemistry, Geophys. Res. Lett., 21, 801-804, 1994.

Prather, M. J. and Spivakovsky, C. M.: Tropospheric $\mathrm{OH}$ and the lifetimes of hydrochlorofluorocarbons, J. Geophys. Res., 95, 18723-18729, 1990.

Prather, M., Gauss, M., Berntsen, T., Isaksen, I., Sundet, J., Bey, I., Brasseur, G., Dentener, F., Derwent, R., Stevenson, D., Grenfell, L., Hauglustaine, D., Horowitz, L., Jacob, D., Mickley, L., Lawrence, M G., von Kuhlmann, R., Muller, J.-F., Pitari, G., Rogers, H., Johnson, M., Pyle, J., Law, K., van Weele, M., and Wild, O.: Fresh air in the 21 st century?, Geophys., Res. Lett., 30, 1100, doi:10.1029/2002GL016285, 2003.

Prather, M. J., Holmes, C. D., and Hsu, J.: Reactive greenhouse gas scenarios: Systematic exploration of uncertainties and the role of atmospheric chemistry, Geophys. Res. Lett., 39, L09803, doi:10.1029/2012GL051440, 2012.
Price, C., Penner, J., and Prather M.: $\mathrm{NO}_{\mathrm{x}}$ from lightning, 1. Global distribution based on lightning physics, J. Geophys. Res., 102, 5929-5941, 1997.

Prinn, R. G., Weiss, R. F., Miller, B. R., Huang, J., Alyea, F. N., Cunnold, D. M., Fraser, P. J., Hartley, D. E., and Simmonds, P. G..: Atmospheric trends and lifetime of $\mathrm{CH}_{3} \mathrm{CCl}_{3}$ and global $\mathrm{OH}$ concentrations, Science, 269, 187-192, 1995.

Prinn, R. G., Huang, J., Weiss, R. F., Cunnold, D. M., Fraser, P. J., Simmonds, P. G., McCulloch, A., Harth, C., Salameh, P., O'Doherty, S., Wang, R. H. J., Porter, L, and Miller, B. R.: Evidence for substantial variations of atmospheric hydroxyl radicals over the past two decades, Science, 292, 1882-1888, 2001.

Prinn, R. G., Huang, J., Weiss, R. F., Cunnold, D. M., Fraser, P. J., Simmonds, P. G., McCulloch, A., Harth, C., Reimann, S., Salameh, P., O’Doherty, S., Wang, R. H. J., Porter, L. W., Miller, B. R., and Krummel, P. B.: Evidence for variability of atmospheric hydroxyl radicals over the past quarter century, Geophys. Res. Lett., 32, L07809, doi:10.1029/2004GL022228, 2005.

Raes, F. and Seinfeld, J. H.: New Directions: Climate change and air pollution abatement: A bumpy road, Atmos. Environ., 43, 51325133, doi:10.1016/j.atmosenv.2009.06.001, 2009.

Rigby, M., Prinn, R. G., Fraser, P. J., Simmonds, P. G., Langenfelds, R. L., Huang, J., Cunnold, D. M., Steele, L. P., Krummel, P. B., Weiss, R. F., O'Doherty, S., Salameh, P. K., Wang, H. J., Harth, C. M., Mühle, J., and Porter, L. W.: Renewed growth of atmospheric methane, Geophys. Res. Lett., 35, L22805, doi:10.1029/2008GL036037, 2008.

Roelofs, G. J., Lelieveld, J., and van Dorland, R.: A threedimensional chemistry-general circulation model simulation of anthropogenically derived ozone in the troposphere and its radiative climate forcing, J. Geophys. Res., 102, 23389-23401, 1997.

Sander, S. P., Friedl, R. R., Golden, D. M., Kurylo, M. J., Huie, R. E., Orkin, V. L., Moortgat, G. K., Wine, P. H., Ravishankara, A. R., Kolb, C. E., Molina, M. J., and Finlayson-Pitts, B. J., Huie, R. E., and Orkin, V. L.: Chemical kinetics and photochemical data for use in atmospheric studies, Evaluation Number 15, JPL Publications 06-2, Jet Propulsion Laboratory, Pasadena, CA, USA, 2006.

Shevliakova, E., Pacala S. W., Malyshev S., Hurtt G. C., Milly P. C. D., Caspersen J. P., Sentman L. T., Fisk J. P., Wirth C., and Crevoisier C.: Carbon cycling under 300 years of land use change: Importance of the secondary vegetation sink, Global Biogeochem. Cy., 23, GB2022, doi:10.1029/2007GB003176, 2009.

Shindell, D. T., Grenfell, J. L., Rind, D., Grewe, V., and Price, C.: Chemistry-climate interactions in the Goddard Institute for Space Studies general circulation model 1, Tropospheric chemistry model description and evaluation, J. Geophys. Res., 106, 8047-8075, 2001.

Shindell, D. T., Faluvegi, G., Bell, N., and Schmidt, G. A.: An emissions-based view of climate forcing by methane and tropospheric ozone, Geophys. Res. Lett., 32, L04803, doi:10.1029/2004GL021900, 2005.

Shindell, D. T., Faluvegi, G., Unger, N., Aguilar, E., Schmidt, G. A., Koch, D. M., Bauer, S. E., and Miller, R. L.: Simulations of preindustrial, present-day, and 2100 conditions in the NASA GISS composition and climate model G-PUCCINI, Atmos. Chem. Phys., 6, 4427-4459, doi:10.5194/acp-6-4427-2006, 2006. 
Shindell, D., Kuylenstierna, J. C. I., Vignati, E., Van Dingenen, R., Amann, M., Klimont, Z., Anenberg, S. C., Muller, N. Z., Janssens-Maenhout, G., Raes, F., Schwartz, J., Faluvegi, G., Pozzoli, L., Kupiainen, K., Hoglund-Isaksson, L., Emberson, L., Streets, D., Ramanathan, V., Hicks, K., Oanh, N. T. K., Milly, G., Williams, M., Demkine, V., and Fowler, D.: Simultaneously mitigating near-term climate change and improving human health and food security, Science, 335, 183-189, 2012.

Sofen, E. D., Alexander, B., and Kunasek, S. A.: The impact of anthropogenic emissions on atmospheric sulfate production pathways, oxidants, and ice core $\Delta^{17} \mathrm{O}\left(\mathrm{SO}_{4}^{2-}\right)$. Atmos. Chem. Phys., 11, 3565-3578, doi:10.5194/acp-11-3565-2011, 2011.

Søvde, O. A., Hoyle, C. R., Myhre, G., and Isaksen, I. S. A.: The $\mathrm{HNO}_{3}$ forming branch of the $\mathrm{HO}_{2}+\mathrm{NO}$ reaction: pre-industrialto-present trends in atmospheric species and radiative forcings, Atmos. Chem. Phys., 11, 8929-8943, doi:10.5194/acp-11-89292011, 2011.

Spivakovsky, C. M., Logan, J. A., Montzka, S. A., Balkanski, Y. J., Foreman-Fowler, M., Jones, D. B. A., Horowitz, L. W., Fusco, A. C., Brenninkmeijer, C. A. M., Prather, M. J., Wofsy, S. C., and McElroy, M. B., Three-dimensional climatological distribution of tropospheric OH: Update and evaluation, J. Geophys. Res., 105, 8931-8980, 2000.

Staffelbach, T., Neftel, A., Stauffer, B., and Jacob, D.: A record of the atmospheric methane sink from formaldehyde in polar ice cores, Nature, 349, 603-605, doi:10.1038/349603a0, 1991.

Stevenson, D. S., Dentener, F. J., Schultz, M. G., Ellingsen, K., van Noije, T. P. C., Wild, O., Zeng, G., Amann, M., Atherton, C. S., Bell, N., Bergmann, D. J., Bey, I., Butler, T., Cofala, J., Collins, W. J., Derwent, R. G., Doherty, R. M., Drevet, J., Eskes, H. J., Fiore, A. M., Gauss, M., Hauglustaine, D. A., Horowitz, L. W., Isaksen, I. S. A., Krol, M. C., Lamarque, J., Lawrence, M. G., Montanaro, V., Müller, J., Pitari, G., Prather, M. J., Pyle, J. A., Rast, S., Rodriguez, J. M., Sanderson, M. G., Savage, N. H., Shindell, D. T., Strahan, S. E., Sudo, K., and Szopa, S.: Multimodel ensemble simulations of present-day and near-future tropospheric ozone, J. Geophys. Res. Atmos., 111, D08301, doi:10.1029/2005JD006338, 2006.

Taylor, K. E., Stouffer, R. J., and Meehl, G. A.: An Overview of CMIP5 and the Experiment Design, B. Am. Meteorol. Soc., 93, 485-498, doi:10.1175/BAMS-D-11-00094.1, 2012.

Thompson, A. M., Chappellaz, J. A., Fung, I. Y., and Kucsera, T. L.: The atmospheric $\mathrm{CH}_{4}$ increase since the Last Glacial Maximum. II - Interactions with oxidants, Tellus, 45, 242-257, doi:10.1034/j.1600-0889.1993.t01-2-00003.x, 1993.

Unger, N., Menon, S., Koch, D. M., and Shindell, D. T.: Impacts of aerosol-cloud interactions on past and future changes in tropospheric composition, Atmos. Chem. Phys., 9, 4115-4129, doi:10.5194/acp-9-4115-2009, 2009. van Vuuren, D., Edmonds, J., Kainuma, M., Riahi, K., Thomson, A., Hibbard, K., Hurtt, G., Kram, T., Krey, V., Lamarque, J.F., Masui, T., Meinshausen, M., Nakicenovic, N., Smith, S., and Rose, S.: The representative concentration pathways: an overview, Clim. Change, 109, 5-31, doi:10.1007/s10584-0110148-z, 2011.

Voulgarakis, A., Naik, V., Lamarque, J.-F., Shindell, D. T., Young, P. J., Prather, M. J., Wild, O., Field, R. D., Bergmann, D., CameronSmith, P., Cionni, I., Collins, W. J., Dalsøren, S. B., Doherty, R. M., Eyring, V., Faluvegi, G., Folberth, G. A., Horowitz, L. W., Josse, B., McKenzie, I. A., Nagashima, T., Plummer, D. A., Righi, M., Rumbold, S. T., Stevenson, D. S., Strode, S. A., Sudo, K., Szopa, S., and Zeng, G.: Analysis of present day and future $\mathrm{OH}$ and methane lifetime in the ACCMIP simulations, Atmos. Chem. Phys. Discuss., 12, 22945-23005, doi:10.5194/acpd-1222945-2012, 2012.

Wang, J. S., Logan, J. A., McElroy, M. B., Duncan, B. N., Megretskaia, I. A., and Yantosca, R. M.: A 3-D model analysis of the slowdown and interannual variability in the methane growth rate from 1988-1997, Global Biogeochem. Cy., 18, GB3011, doi:10.1029/2003GB002180, 2004.

Wang, Y. and Jacob, J. D.: Anthropogenic forcing on tropospheric ozone and $\mathrm{OH}$ since preindustrial times, J. Geophys. Res., 103, 31123-31135, 1998.

Warwick, N. J., Bekki, S., Law, K. S., Nisbet, E. G., and Pyle, J. A.: The impact of meteorology on the interannual growth rate of atmospheric methane, Geophys. Res. Lett., 29, 1947, doi:10.1029/2002GL015282, 2002.

West, J. J., Fiore, A. M., Horowitz, L. W., and Mauzerall, D. L.: Global health benefits of mitigating ozone pollution with methane emission controls, Proc. Natl. Acad. Sci., 103, 39883993, doi:10.1073/pnas.0600201103, 2006.

Wild, O. and Palmer, P. I.: How sensitive is tropospheric oxidation to anthropogenic emissions?, Geophys. Res. Lett., 35, L22802, doi:10.1029/2008GL035718, 2008.

Young, P. J., Archibald, A. T., Bowman, K. W., Lamarque, J.-F., Naik, V., Stevenson, D. S., Tilmes, S., Voulgarakis, A., Wild, O., Bergmann, D., Cameron-Smith, P., Cionni, I., Collins, W. J., Dalsøren, S. B., Doherty, R. M., Eyring, V., Faluvegi, G., Horowitz, L. W., Josse, B., Lee, Y. H., MacKenzie, I. A., Nagashima, T., Plummer, D. A., Righi, M., Rumbold, S. T., Skeie, R. B., Shindell, D. T., Strode, S. A., Sudo, K., Szopa, S., and Zeng, G.: Pre-industrial to end 21 st century projections of tropospheric ozone from the Atmospheric Chemistry and Climate Model Intercomparison Project (ACCMIP), Atmos. Chem. Phys. Discuss., 12, 21615-21677, doi:10.5194/acpd-12-21615-2012, 2012. 